\title{
Review \\ The Roles of MADS-Box Genes from Root Growth to Maturity in Arabidopsis and Rice
}

\author{
Liaqat Shah ${ }^{1,2}$, Amir Sohail ${ }^{1}$, Rafiq Ahmad ${ }^{3}$, Shihua Cheng ${ }^{1}$, Liyong Cao ${ }^{1,4, *}$ and Weixun Wu ${ }^{1, *}$ (i) \\ 1 China National Center for Rice Improvement, China National Rice Research Institute, Hangzhou 310006, China; \\ liaqatpbg@yahoo.com (L.S.); amirsohail@aup.edu.pk (A.S.); chengshihua@caas.cn (S.C.) \\ 2 Department of Agriculture, Mir Chakar Khan Rind University, Sibi 82000, Pakistan \\ 3 Department of Botany, Mir Chakar Khan Rind University, Sibi 82000, Pakistan; rafiqnenu2015@gmail.com \\ 4 Northern Center of China National Rice Research Institute, Hangzhou 310006, China \\ * Correspondence: caoliyong@caas.cn (L.C.); wuweixun@caas.cn (W.W.)
}

check for updates

Citation: Shah, L.; Sohail, A.;

Ahmad, R.; Cheng, S.; Cao, L.; Wu, W. The Roles of MADS-Box Genes from Root Growth to Maturity in Arabidopsis and Rice. Agronomy 2022, 12, 582. https://doi.org/10.3390/ agronomy12030582

Received: 28 December 2021 Accepted: 21 February 2022 Published: 26 February 2022

Publisher's Note: MDPI stays neutral with regard to jurisdictional claims in published maps and institutional affiliations.

Copyright: (C) 2022 by the authors. Licensee MDPI, Basel, Switzerland. This article is an open access article distributed under the terms and conditions of the Creative Commons Attribution (CC BY) license (https:// creativecommons.org/licenses/by/ $4.0 /)$.

\begin{abstract}
Rice (Oryza sativa L.) and Arabidopsis thaliana (L.) life cycles involve several major phase changes, throughout which MADS-box genes have a variety of functions. MADS-box genes are well recognized for their functions in floral induction and development, and some have multiple functions in apparently unrelated developmental stages. For example, in Arabidopsis, AGL15 and AGL6 play roles in both vegetative development and floral transition. Similarly, in rice, OsMADS1 is involved in flowering time and seed development, and OsMADS26 is expressed not only in the roots, but also in the leaves, shoots, panicles, and seeds. The roles of other MADS-box genes responsible for the regulation of specific traits in both rice and Arabidopsis are also discussed. Several are key components of gene regulatory networks involved in root development under diverse environmental factors such as drought, heat, and salt stress, and are also involved in the shift from vegetative to flowering growth in response to seasonal changes in environmental conditions. Thus, we argue that MADS-box genes are critical elements of gene regulation that underpin diverse gene expression profiles, each of which is linked to a unique developmental stage that occurs during root development and the shift from vegetative to reproductive growth.
\end{abstract}

Keywords: MADS-box gene; root growth; floral transition; seed setting; inflorescence branching

\section{Introduction}

MADS-box genes are a family of transcription factors initially discovered in eukaryotes [1]. All MADS-box proteins have a DNA-binding MADS domain that is 60 amino acids in length [2]. There are two types of MADS-domain proteins: Type I and Type II. The functions of Type I proteins in plants are mostly unclear [3]. Type II proteins (also known as MIKC-type proteins) are distinguished by the presence of four different domain structures known as the MADS, keratin-like, intervening, and C-terminal domains [4]. MIKC-type MADS-box genes are known to play roles in plant development from vegetative growth to reproduction and to function in various stress responses [5].

The conserved MADS (M) domain and a substantial variable area at the C-terminus are found in Type I proteins, also known as the M-type [6]. In addition to the MADS DNA binding activity, the $\mathrm{M}$ domain contains an I domain, a $\mathrm{K}$ domain, and a $\mathrm{C}$ domain in Type II proteins [7]. The I domain is required for DNA dimerization and specificity [8], whereas the $\mathrm{K}$ domain is required for both dimer formation and tetramerization $[9,10]$. The $\mathrm{C}$ domain, a highly variable and largely unstructured domain based on secondary structure prediction, is important in transcriptional activation and the development of higher-order transcription factor (TF) complexes. The $\mathrm{C}$ domain also contributes to MADSbox protein-protein interactions [10,11]. Based on the ABCDE model, M-type MADS-box genes have been reported to be involved in plant reproduction, specifically the development and functioning of female gametophytes, the embryo, and the endosperm; MIKC-type 
MADS-box genes are involved in meristem differentiation, flowering, the determination of floral organ identity, and fruit development [11].

Genetic studies in rice and Arabidopsis have revealed the functions of several MADSbox genes in plant development. The majority of these studies have shown that MADS-box genes are engaged in a variety of important morphological and physiological functions, including gametophyte cell division, root development, the floral transition, and floral organ control [12-14]. A typical dicot flower is divided into four parts (whorls): petals, sepals, pistils, and stamens. The generally accepted ABCDE model of floral organs is based on research in dicot species such as Antirrhinum majus and Arabidopsis [15,16]. Different floral organ identities are regulated by various gene combinations, namely $\mathrm{A}+\mathrm{E}$ (sepals), A + B + E (petals), B + C + E (stamens), C + E (carpels), and D + E (ovules). A great majority of these genes encode MADS-box TF that have been linked to floral organ development [17-21].

In Arabidopsis and rice, MADS-box genes play roles in a variety of developmental processes, including root development and elongation, meristem specification, the flowering transition from vegetative to reproductive stage, endosperm and seed formation, flower development and fertility, and fruit ripening. Several published reviews have reported on their functions from vegetative transition to reproductive development [1,11,22-28].

\section{MADS-Box Gene Expression Profiles during Root Development}

MADS-box genes are involved in various components of root development [29], affecting the formation of primary and lateral roots, root density, and root elongation. More than 50 MADS-box genes have been reported to be expressed in Arabidopsis roots [30]. However, little is known about their role in root growth and development during environmental stress exposure. In Arabidopsis, many MADS-box genes of the MIKC type, specifically AGL17-like clade genes, regulate root formation [31,32]. Three members of the AGL17-like clade, namely AGL17, AGL21, and ANR1, are dominantly expressed in Arabidopsis roots [30,33-35]. Expression of the nitrate transporter gene NRT2.1 is reduced in the roots of an anr1 mutant line, demonstrating that ANR1 is a positive regulator of NRT2.1 in Arabidopsis [36]. ANR1 stimulates lateral root elongation and increases the fresh weight of shoots in the presence of nitrate by promoting lateral meristem activity $[33,37]$. In contrast, AtAGL21 increases auxin biosynthesis in the absence of nitrate, promoting lateral root development and elongation [33,37,38]. Intriguingly, ANR1 expression was drastically reduced in $n r t 1.1$ mutants, and these mutants displayed reduced root elongation in nitrate-rich conditions compared with ANR1-knockout plants [33,39]. These findings demonstrate that NRT1.1 functions upstream of ANR1 in local nitrate-induced lateral root development. The key roles of ANR1 in shoot development and in response to nitrate stress remain to be investigated. Overexpression of miR444a decreases shoot development at the seedling stage [40]. Future research should also focus on miR444a and ANR1 may work cooperatively or independently to understand the function of ANR1 under nitrate stress exposure in processes such as shoot development at the seedling stage. The MADS-box TF AGL16 functions as a negative regulator under saline conditions. The agl16 mutants are salt stress-resistant concerning root elongation in comparison to wild-type plants [41]. In Arabidopsis, AGL42 expression has been utilized as a marker for quiescent center identity cells [42], which are the cells at the apices of stele and cortex histogens. However, the loss-of-function mutant has no clear abnormal phenotype in the root, demonstrating that its role in root elongation is unknown. Furthermore, it has been shown that upregulation of AGL42 in the quiescent center and the stele depends on expression of the Brassinosteroid receptor BRI1 on epidermal cells [43].

In rice, AGL17-like clade genes such as OsMADS57 regulate root growth and elongation $[29,44,45]$. OsMADS57 promotes seminal and adventitious root elongation as well as root to shoot nitrate translocation by influencing the expression of NRT2 [46,47], whereas overexpression of OsMADS57 in rice increases the rate of seed germination and root elongation in response to salt stress conditions [48]. It remains to be determined whether 
OsMADS57 overexpression promotes tolerance to other environmental stress factors such as drought or heat. Additional research should be conducted to understand the OsMADS57mediated stress signaling pathway to ultimately strengthen crop tolerance to adverse environmental factors through genome editing technology.

OsMADS50/OsSOC1 (Oryza Sativa SUPPRESSOR OF OVEREXPRESSION OF CO 1) was shown to be important in the control of crown root growth [49]. Plants overexpressing ANR1 showed increased lateral root density and longer lateral roots under control conditions and high nitrogen levels [37]. Furthermore, the rice ANR1 gene family members OsMADS27, OsMADS25, and OsMADS61 are expressed in the root vasculature, and their transcription is modulated differentially in response to $\mathrm{NO}_{3}{ }^{-}$deficiency, $\mathrm{NO}_{3}{ }^{-}$resupplementation, and a variety of environmental conditions $[35,44]$. In the presence of nitrate, OsMADS25-overexpression lines showed increases in the number and density of lateral roots while producing significantly larger primary roots; knocking down OsMADS25 had the opposite effect on transgenic rice plants. In addition, OsMADS25 is involved in the regulation of nitrogen transporter genes, demonstrating that this $\mathrm{TF}$ is a key regulator of primary and lateral root formation in rice [29]. In the absence of $\mathrm{NO}_{3}{ }^{-}$, overexpression of OsMADS25 resulted in increased lateral root number and primary root length in Arabidopsis compared with wild-type plants. OsMADS27-overexpression lines of rice produced more lateral roots but had shorter primary roots in a $\mathrm{NO}_{3}{ }^{-}$dependent manner. Surprisingly, OsMADS27 overexpression improved salt tolerance, most likely via changes in ABA signaling [50]. Similarly, phosphate deficit and phosphorus supplementation decreased the expression of OsMADS23, OsMADS25, and OsMADS27, but sulphur deficiency increased the expression of these genes significantly [35]. In a yeast two-hybrid experiment, OsMADS27 was shown to bind to a protein implicated in ABA signaling (ABI5; [50]). Os$M D P 1$ encodes a rice AG-like MADS-box protein found in vegetative tissues such as the coleoptile, mature leaf, culm internode, root-elongation zone, and most significantly, the joining area between the leaf blade and the sheath [51]. These findings indicate that several MADS-box genes are critical in root development in many species, and that they respond to environmental conditions through complicated regulatory mechanisms.

Expression of the XAANTAL1 (XAL1; formerly known as AGL12) ortholog OsMADS26 increases with age in rice, and overexpression of this MADS-box gene produces a variety of stress-related responses, including decreased root growth and development [52]. Furthermore, another XAL1 ortholog, LOC_Os08g02070, is expressed preferentially in the rhizome tips in another rice species, Oryza longistaminata [53]. Analysis of the root transcriptome in wild emmer wheat (Triticum turgidum ssp. dicoccoides (Körn.) Thell.) showed that the OsMADS26 ortholog MADS26 was upregulated in a drought-resistant genotype compared to a drought-susceptible line, implying that XAL1 homologs contribute to varying degrees to stress responses and plant development [54]. XAL1 is expressed during the development of various organs, suggesting that it is a key component in complex networks that affect multiple aspects of plant development. Furthermore, it is likely to be implicated in both vegetative and reproductive epidermal cell patterning under different environmental circumstances. However, additional research is required to test this hypothesis. Future research should also focus on protein-protein interactions to understand the function of $X A L 1$ in processes such as root growth.

\section{MADS-Box Gene Expression Profiles during Leaf Development in Rice}

It has been shown that OsMADS22 and OsMADS55 encode negative regulators of brassinosteroid responses, although their functions differ significantly by developmental stage. OsMADS47 is expressed at high levels in seedling leaves, whereas the transcription of OsMADS55 is highest in mature leaves. As a result of these contrasting expression patterns, OsMADS55 and OsMADS47 are the primary negative regulators of brassinosteroid responses in leaves [55]. In the lamina joint of flag leaves in osmads22 osmads47 osmads55 triple mutant plants, two genes downstream of brassinosteroid synthesis (OsXTR1 and OsBLE3) were upregulated, whereas expression of two brassinosteroid biosynthesis 
genes (DWARF2 and BRD1) did not significantly change. These findings suggest that genes in the short vegetative phase group interfere with the downstream signaling of OsXTR1 and OsBLE3. Further studies into the interactions between proteins encoded by brassinosteroid-responsive genes and downstream target genes are needed to verify this hypothesis. Transgenic plants with reduced levels of OsMADS55 or OsMADS47 expression show brassinosteroid-related aberrant phenotypes [51].

Gibberellic acid (GA) plays an important role in the regulation of seed germination, leaf shape, and flowering. The gibberellic acid response element, the P-box, is present in the promoter region of PvSOC1, but not in the promoters of SOC1/AGL20 or OsSOC1. The expression of PvSOC1, from the bamboo Phyllostachys violascens, was found to be higher in the leaves of seedlings after GA treatment, indicating a positive response to GA. PvSOC1 appears to be a multifunctional gene that influences leaf development and flowering [56]. PvSOC1 over-expression in Arabidopsis and rice resulted in early flowering, abnormal floral organs, and deformed leaves. However, further research is required to identify the function of PvSOC1 in rice and Arabidopsis.

\section{MADS-Box Genes Are Responsible for Inflorescence Branching}

The molecular processes driving the evolutionary and developmental dynamics of inflorescences are largely unknown. This is in contrast to the relatively well-understood genetic foundation of floral diversity, where MADS-box TFs have been revealed to play a key role in reproductive processes [57,58]. Grasses (Poaceae), which include cereal crops such as rice, have a different inflorescence design than eudicots such as Arabidopsis. Spikelets, which are physically separate structural components, make up the inflorescence in grasses. In Arabidopsis, it has been reported that both APETALA1 (AP1; formerly known as AGL7) and LEAFY (LFY) inhibit inflorescence branching through interaction with the TERMINAL FLOWER1 (TFL1) gene [59-61]. Furthermore, two AP1 homologs, CAULIFLOWER (CAL) and FRUITFULL (FUL; formerly known as AGL8) repress the expression of TFL1. This was verified in ap1 cal ful triple mutants, in which TFL1 functions in conversion of floral meristems into inflorescences [62]. Four MADS-box TFs, SOC1, SVP, AGL24, and SEPALLATA 4 (SEP4), suppress inflorescence branching by directly inhibiting TFL1 expression in Arabidopsis [63]. It was further demonstrated that SVP, SOC1, AGL24, and SEP4 orthologs in rice control panicle branching by modulating TFL1-like genes. These findings demonstrate the existence of a conserved genetic mechanism in flowering plants that determines inflorescence morphology. Studies of the gene expression programs downstream from $L F Y$ and AP1 have shown that LFY and AP1 share several target genes and frequently bind to contiguous locations in the Arabidopsis genome [59,64-67]. The findings of a metaanalysis of existing genome-wide data sets for the two TFs confirmed a common set of target genes [66]. LFY and AP1 regulate the expression of $\sim 200$ genes, many of which are known regulators of floral development and branching. These common targets most likely form the molecular foundation of the partial redundancy observed between AP1/CAL and $L F Y$ in floral development. However, it is still unknown whether LFY and AP1/CAL work independently or cooperatively in regulating the common target genes. MADS-box genes reported participating in different developmental processes of Arabidopsis are tabulated in Table 1.

TFL1 has an apparently conserved function; mutant rice plants ectopically expressing TFL1 orthologs exhibit massive inflorescence branching [63,68]. It is therefore unknown how TFL1-like genes are expressed in flowering plants to define specific types of inflorescence design. In eudicots and monocots, TFL1-like genes are needed for meristem indeterminacy [68-71]. Upregulation of the TFL1 homologs RCN1 and RCN2 in rice and ZCN1 to ZCN6 in maize results in a branched inflorescence $[68,70]$. Future research should examine the relationships between these MADS-box genes and other inflorescence characteristics. For example, a study of OsMADS34, FLORAL ORGAN NUMBER4 (FON4), and LAX PANICLE1 (LAX1) showed superior phenotypes of osmads34 fon4 and osmads34 lax1 double mutants compared with the single mutants; OsMADS34 interacts with LAX1 and 
FON4 to regulate many features of inflorescence shape, branching, and meristem activity. Furthermore, a double mutant combining the sterile lemma-defective and osmads 34 mutants had longer and wider sterile lemmas, indicating that ELONGATED EMPTY GLUME (ELE) and OsMADS34 work together to control sterile lemma development. OsMADS34 and OsMADS15 may also cooperate to control the development of sterile lemmas [72].

Table 1. Roles of MADS-box genes in the development of Arabidopsis thaliana (L.).

\begin{tabular}{|c|c|c|c|}
\hline Gene & Locus ID & Function & Reference \\
\hline STK/AGL11 & At4g09960 & Ovule development & {$[19,30]$} \\
\hline XAL1/AGL12 & At1g71692 & Root development; transition to flowering & [73] \\
\hline AGL15 & AT5g13790 & $\begin{array}{l}\text { Embryogenesis; sepal and petal longevity; flowering repressor with AGL18; } \\
\text { fruit maturation }\end{array}$ & [74-76] \\
\hline AGL18 & At3g57390 & Flowering repressor with AGL15 & [77] \\
\hline AGL16 & At3g57230 & Number and distribution of stomata & [78] \\
\hline AGL17 & At2g22630 & Root formation; Flowering activator & {$[31,32,79]$} \\
\hline AGL6 & At2g45650 & Flowering activator; lateral organ development & [80] \\
\hline FLC/AGL25 & At5g10140 & $\begin{array}{l}\text { Juvenile-to-adult transition; flowering repressor; flowering initiation, } \\
\text { flower organ development }\end{array}$ & {$[81,82]$} \\
\hline MAF2/AGL31 & At5g65050 & Flowering repressor & [83] \\
\hline AGL19 & At4g22950 & Flowering activator & [84] \\
\hline FUL/AGL8 & At5g60910 & $\begin{array}{l}\text { Meristem identity specification; annual life cycle regulator with SOC1; fruit } \\
\text { development }\end{array}$ & {$[62,85]$} \\
\hline$A P 1 / A G L 7$ & At1g69120 & Homeotic A-class gene; meristem identity specification & [62] \\
\hline AGL24 & At4g24540 & Flowering activator & [86] \\
\hline AGL23 & At1g65360 & Embryo sac development & [87] \\
\hline AGL28 & At1g01530 & Flowering activator & [88] \\
\hline AGL42 & At5g62165 & A marker for quiescent center identity cells & [42] \\
\hline AGL62 & At5g60440 & Central cell development & [89] \\
\hline
\end{tabular}

\section{Communicating Role from Vegetative to Flowering Transition}

One of the most basic developmental alterations in the life cycle of flowering plant species is the change from the vegetative to the reproductive stage [90]. Several investigations have shown that flower growth in higher eudicot angiosperms is controlled by a hierarchical network of regulatory genes [91]. Late- and early-flowering genes, which are regulated by diverse environmental factors such as light quality, day length, and heat, are at the top of the hierarchy. These genes may regulate the conversion from vegetative to flowering development by activating meristem identity genes in response to environmental factors.

In Arabidopsis, SPLs are upstream activators and downstream targets of the floraltransition MADS-box genes. Photoperiod strongly affects transcription of three miR156targeted SPLs (SPL3, SPL4, and SPL5), which are downregulated in short-day (SD) conditions and upregulated in long-day (LD) conditions [92]. Another study demonstrated that SPL3, SPL4, and SPL5 act in a dependent manner upon two related BELL1-like homeodomain proteins, PENNYWISE (PNY) and POUND-FOOLISH (PNF), which act to specify floral meristems through downregulation of miR156 [93]. This effect was verified in pny pnf double mutants, in which expression levels of AP1 and three SPLs were drastically reduced and plants were not able to produce flowers in response to inductive conditions. Further research is needed to determine whether miR156 regulation of flowering is dependent on the expression of PNY and PNF. SPL3 is regulated directly by SOC1 [94]; SPL4 expression is 
greatly decreased in soc1 ful double mutants in the SAM [94,95]. This interconnected feedforward loop may promote the transition from vegetative to reproductive development. The reduction in miR156 accumulation in agl15 agl18 double mutants demonstrates that AGL15 and AGL18 function as co-regulators with miR156 in the determination of flowering time in Arabidopsis. AGL15 and AGL18 interact with putative CArG motifs in the MIR156 promoter both in vitro and in vivo [96-98].

In Arabidopsis, GA enhances the transition from vegetative to flowering development by degrading transcriptional repressors DELLAs. However, the underlying processes are still unknown. DELLA proteins interact with microRNA156-targeted SPL TFs to repress transcriptional activation of MADS-box genes such as AP1, SOC1, and FUL, plant-specific LEAFY (LFY) TFs, and miR172 [99-102].

In rice, the MADS protein family has 75 members, which are mainly divided into five categories: MIKCC, MIKC, $\mathrm{M} \alpha, \mathrm{M} \beta$, and $\mathrm{M} \gamma$. Most are involved in regulating the formation of floral organs [103] but MADS-box TFs are also related to several processes in vegetative plant growth and development. There have been no reports of rice genes with substantial similarity to FLOWERING LOCUS C (FLC; formerly known as AGL25) outside of the MADS genes; however, the MADS-box gene OsMADS50/OsSOC1 has a similar sequence to that of AtSOC1. It has been shown that OsMADS50/OsSOC1 is transcribed at a somewhat higher level during the floral transition than during vegetative growth, and that OsMADS50/OsSOC1 over-expression causes transgenic Arabidopsis plants to flower early [104].

OsMADS50 and OsMADS56 encode MIKCC-type proteins that are homologs of Arabidopsis $S O C 1$, and the expression of both is affected by the circadian clock $[105,106]$. Under LD conditions, OsMADS50 and OsMADS56 have opposing effects on flowering time in rice. OsMADS56 is a flowering suppressor gene, whereas OsMADS50 can promote flowering. In Arabidopsis, SOC1 is a downstream target gene of CONSTANS (CO), whereas OsMADS50 and OsMADS56 are upstream of the flowering time regulatory network in rice. In addition, expression analyses and interaction experiments for related genes have shown that they also control flowering in rice by forming an antagonistic complex to regulate the common downstream gene OsLFL1-Ehd1 (Early heading date 1). They are also independent of flowering regulation by Hd1, SE5, and RID1/OsId1 / Ehd2 [107].

Rice flowering time is determined by the expression levels of three additional $S E P$-like MADS-box genes, OsMADS7, OsMADS5, and OsMADS8 [108,109]. TaMADS1, a wheat homolog of rice OsMADS24, regulates floral development, and ectopic expression of TaMADS1 induces early flowering in Arabidopsis [5]. Overexpression of TaMADS1 also induces early flowering and abnormal floral organ development in Arabidopsis [110]. Furthermore, TaAGL6 overexpression also promotes early flowering in Arabidopsis [111]. Several studies have shown that specific MADS-box genes in wheat affect flowering; however, compared to species such as Arabidopsis and rice, there is still a great deal to be uncovered.

OsMADS14, OsMADS15, and OsMADS18 are all AP1/FUL genes that encode flowering promoting factors that function downstream of OsMADS50 [105,112]. RNAi-mediated suppression of these three genes results in a slight delay in the reproductive transition [112]. OsMADS51 and OsMADS65 are MADS-box genes of the MIKCC type, and OsMADS51 encodes a TF that promotes flowering under SD conditions [113].

\section{Molecular Events at the Shoot Apical Meristem in Response to Photoperiodic Induction}

Arabidopsis Florigen gene FLOWERING LOCUS T (FT) transcription and migration of the encoded protein to the apical meristem are induced by inductive photoperiods, which alter the regulation of genes involved in inflorescence formation. The FT-FD complex in Arabidopsis shoot apical meristems is directed to the promoter of AP1, which encodes a MADS-box TF required for flowering initiation and flower development [114]. Additional MADS-box TFs that are necessary for $F T$-stimulated flowering, such as $S O C 1$, is upregulated early in the floral conversion. In Arabidopsis, SOC1 is regulated by two flowering regulators, $C O$ and $F L C$, which function as a floral activator and repressor, respectively $[100,115,116]$. 
Other genes, such as FD PARALOGUE (FDP), may share FD function [114,117]. TWIN SISTER OF FT (TSF) and FD activation by $N^{6}$-benzylaminopurine treatments and physical interaction between TSF and FD or FDP proteins [118] demonstrated that a TSF/FD(P) complex is involved in promoting flowering [119]. Expression levels of both TSF and FDP increased simultaneously in the leaves after $N^{6}$-benzylaminopurine application, suggesting that the TSF /FD complex may function in leaves. This was a surprising finding because FD is primarily expressed in Arabidopsis root and shoots apices [114,117]. However, it has also been reported that $F D$ is necessary for $F T$ to increase gene expression in leaves [120], and the $F D$ homolog SPGB (an AG-box factor called SPGB with a specific 14-3-3 adapter protein) is expressed in both leaves and shoot apices in tomato [121]. The discovery of the TSF protein in phloem sap [122] demonstrates that it could be a systemic signal. This indicates that $N^{6}$-benzylaminopurine initiates flowering by promoting transcription of TSF, which then travels to the meristem and stimulates SOC1 and AP1 transcription by contact with FD or FDP. Prior to the floral transition, flowering repressors are also present in the meristem. FLC and SVP encode MADS-box proteins that significantly delay flowering [99,123-125]. These proteins form a heterodimer that is hypothesized to suppress SOC1 transcription [126,127]. However, a study revealed that the flowering time was increased in flc sop double mutants compared with either single mutant, implying that these proteins have both unique and overlapping functions. Both proteins delay flowering by suppressing FT and TSF or SOC1 transcription in the leaf and meristem, respectively $[118,128,129]$. The MADS-box floral activator FUL functions redundantly with $S O C 1$, as demonstrated by the phenotypes of soc1 and ful single mutants $[62,85,95]$. The soc1 ful double mutants had increased abnormalities in floral initiation and reproductive growth maintenance.

Both $H d 3 a$ and OsFD1 expression are necessary in rice protoplasts to stimulate the expression of OsMADS15, a homolog of AP1. The $h d 3 a$ mutants that cannot bind to 14-3-3 proteins and 14-3-3 knockouts are unable to stimulate OsMADS15 transcription [130]. Rice has a counterpart to $S O C 1$ that is regulated by OSMADS50 and has been found to be necessary for flowering induction [105]. The MADS-box genes OsMADS14, OsMADS18, and OsMADS34 are required for normal inflorescence development, and their expression is elevated in the SAM during the flowering transition [112]. These findings point to the presence of a conserved floral initiation strategy in plant apical meristems, in which florigens interact with FD-like TFs to induce transcription of several MADS-box genes slightly earlier in the transition from vegetative growth to flowering. This core developmental plan is linked to additional regulatory layers in order to fine-tune and sustain the floral transition $[131,132]$. Figure 1 includes several MADS-box genes responsible for root, seedling, flowering, ovule, and pollen grain development of Arabidopsis. 


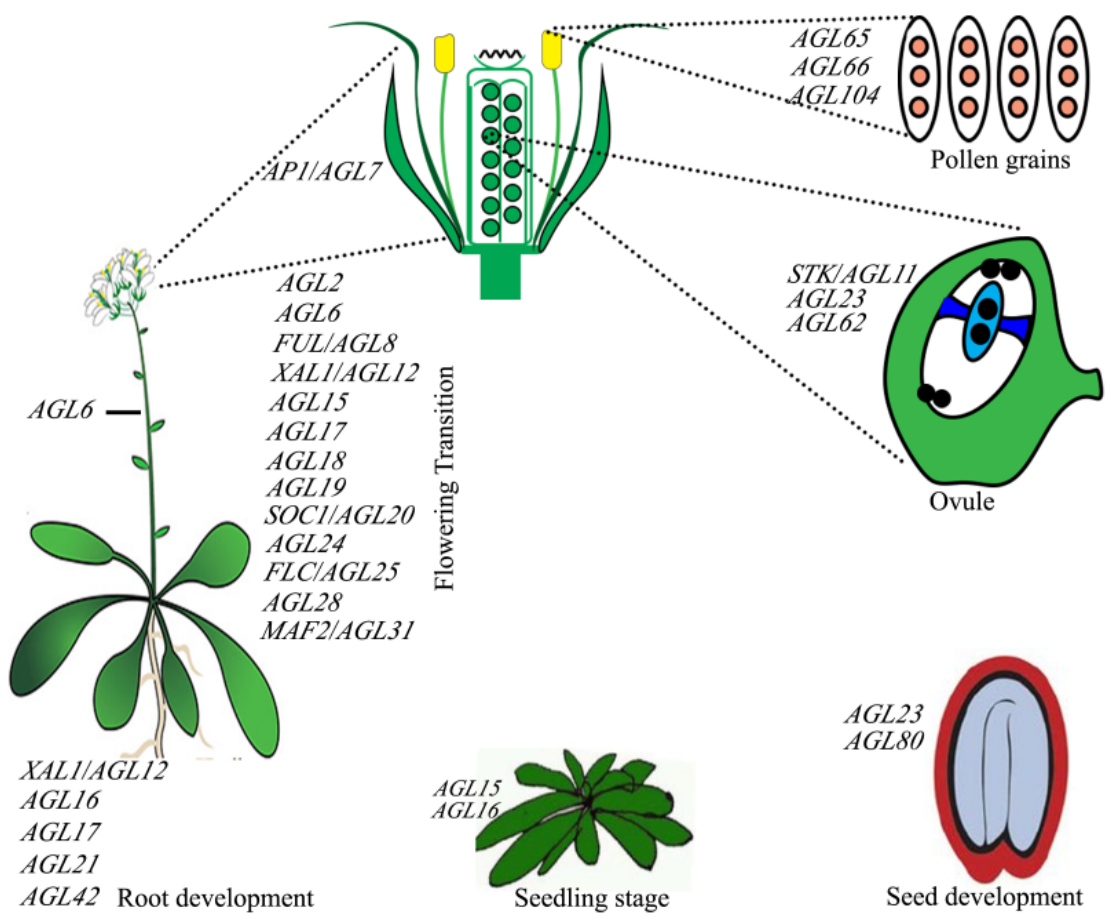

Figure 1. The biological roles of MADS-box genes in controlling the development of various vegetative and reproductive tissues of the model plant Arabidopsis thaliana. Many MADS-box genes mediate the transition to flowering. Some MADS-box genes are involved in flowering time, such as AGL2 [133,134], AGL6 [80], FUL/AGL8 [62,85], XAL1/AGL12 [73], AGL15 [74-76], AGL17 [79], AGL18 [77], AGL19 [84], SOC1/AGL20 [100], AGL24 [135], FLC/AGL25 [81,82], AGL28 [88], and MAF2/AGL31 [83]. MADS-box genes are also involved in root growth (e.g., XAL1/AGL12, AGL16, AGL17, AGL21, and AGL42) [31,32,42,73,78,79,136], pollen maturation and tube growth (AGL65/66/104) [137], ovule development (e.g., STK/AGL11, AGL23, AGL62) [19,30,87,89], and seed development (e.g., AGL23, AGL80) [87,138].

\section{Floret Pattern Initiation and Development}

Although key aspects related to the genesis and diversity of flowers remain largely unknown, the genetic control of flower shape has been widely investigated in diverse crop species [139].

MADS-box proteins regulate inflorescence development by establishing a higher-order combination, and rice has a large number of MADS-box genes [140]. The four putative A-class genes in rice are OsMADS14, OsMADS18, OsMADS15, and OsMADS20 [140,141]. The double knockouts osmads14 osmads15 exhibit genuine homozygous genetic variation, with abnormalities in the first and second whorls. The A-class gene OsMADS15 has been demonstrated to be involved in palea development in a previous study [142]. Triple mutant osmads14 osmads15 osmads18 plants show no phenotypic changes in floral development [112]. Rice also has two B-class orthologs, OsMADS2 and OsMADS4. It was demonstrated that osmads4 mutant plants have normal lodicule and stamen characteristics, whereas transgenic plants in which OsMADS2 silenced show differences in the lodicules but not in the stamens. Instead of lodicules and carpel-like organs, transgenic plants lacking both OsMADS4 and OsMADS2 have palea-like structures [143-146]. The C-class gene OsMADS3 is associated with meristem function in early and late floral development [147], whereas the D-class gene OsMADS13 is required for ovule identity [148]. OsMADS3 is mainly involved in the presumptive region of stamen and ovule primordia just before the initiation of these organs [148]. Furthermore, OsMADS58 is upregulated in reproductive organs. However, loss-of-function mutants for OsMADS3 have abnormal stamens but normal carpel development. The osmads58 mutant has decreased floral meristem determinacy instead of floral organ abnormalities. When OsMADS3 and OsMADS58 were silenced, the 
male and female reproductive organs were homeotically transformed into palea/lemmalike organs and lodicules [148]. It is possible that differences in the proteins that interact with OsMADS3 and OsMADS58 resulted in functional diversity. The precise molecular mechanism behind the functional diversification of OsMADS3 and OsMADS58 remains an interesting subject for future study. Overexpression of SVP-group MADS-box genes produces flower deformities and floral reversion in Arabidopsis and barley [135,149], and Sentoku et al. [150] showed that OsMADS22-overexpressing plants exhibit comparable traits. Fertility and panicle length were also affected in OsMADS22-overexpressing plants. Similarly, OsMADS55 overexpression lines showed reduced fertility, shorter panicles, and malformed flowers [55].

OsMADS1, a SEP-like subfamily homolog, is expressed in the lemma and palea and affects floral meristem identity [151]. The interaction of OsMADS1 with B-, C-, and Dclass proteins has been confirmed by yeast two-hybrid analysis; this interaction produces a heterodimeric complex that influences floral meristem determinacy. The interaction of OsMADS1 with OsMADS3 and OsMADS58 to determine stamen identity and prevent spikelet meristem reversion has been demonstrated both in vitro and in vivo. Furthermore, OsMADS1 is a positive regulator of OsMADS17 during floral development, whereas Os$M A D S 1$ and OsMADS13 function in meristem determinacy through partially independent pathways. These findings suggest that OsMADS1 collaborates with another unknown regulator to modulate meristem determinacy. OsMADS1 and OsMADS34 are involved in the development of the four whorls of the floral organs as well as the development of spikelet meristems [152]. This finding has been verified in osmads34 osmads1 double mutants, demonstrating that OsMADS34 determines rice floral organ identity in combination with OsMADS1.

The S-clade genes OsMADS62 and OsMADS63, as well as the P-clade gene OsMADS68, are MIKC-type genes in rice. All three MIKC-type genes were found to be expressed in the late developmental stages of pollen. Proteins from the different sub-clades form heterodimers, which is very similar to the process that occurs in Arabidopsis [153,154]. OsMADS62, OsMADS63, and OsMADS68 transcripts are found in pollen but not in the anther walls. These findings show that rice MIKC-type genes are only expressed in pollen at late developmental stages, implying that they participate in pollen maturation [153]. The osmads62 osmads63 osmads68 triple knockout mutants have a male-sterile phenotype [155], similar to that of the rice immature pollen 1 (rip1) mutant. RIP1 functions in normal pollen development, and rip1 mutants have a male-sterile phenotype and abnormal intine layers [156]. Furthermore, RIP1 is not expressed in osmads62 osmads63 osmads68 triple mutants. It has been predicted that RIP1 may function upstream of OsMADS62, OsMADS63, and OsMADS68, or in a different pathway containing those three MADS genes. Further study is required to verify this prediction. MADS-box genes reported participating in different developmental processes of rice are tabulated in Table 2.

In Arabidopsis, several genes play critical roles in floret development. TM5, FBP2, and other AGL2-like genes are expressed in the petals and stamens [133,157,158]. In addition, the AGL2-like genes serve as facilitators between the floral organ identity and floral meristem genes in Arabidopsis [133,134]. SEEDSTICK (STK; formerly known as AGL11), SHATTERPROOF (SHP) 1, and SHP2 are three D-class genes in Arabidopsis that have overlapping functions in regulating ovule development $[19,159,160]$. This redundancy has been verified through phenotyping single and triple mutants. XAL1/AGL12, the sole member of the subfamily in Arabidopsis, is expressed in flowers [34]. 
Table 2. MADS-box genes have different functions in different parts of the rice plant.

\begin{tabular}{|c|c|c|c|}
\hline Gene & Genomic Identity & Function & Reference \\
\hline OsMADS1 & LOC_Os03g11614 & Involved in the early stages of rice floret development & [161] \\
\hline OsMADS3 & LOC_Os01g10504 & $\begin{array}{l}\text { Meristem function in early and late floral development, involved in the } \\
\text { formation of stamens and ovules }\end{array}$ & [147] \\
\hline OsMADS5 & LOC_Os06g06750 & Expressed strongly across a broad range of reproductive stages and tissues & [162] \\
\hline OsMADS7 & LOC_Os08g41950 & Improves the stability of rice amylose content at high temperature & [163] \\
\hline OsMADS8 & LOC_Os09g32948 & Inflorescence branch meristems & [152] \\
\hline OsMADS13 & LOC_Os12g10540 & Ovule identity & [148] \\
\hline OsMADS14 & LOC_Os03g54160 & Flowering activator & [112] \\
\hline OsMADS15 & LOC_Os07g01820 & Flowering activator & [112] \\
\hline OsMADS16 & LOC_Os06g49840 & Regulation of floral organ development and pollen formation & [164] \\
\hline OsMADS17 & LOC_Os04g49150 & Regulates hormone signaling and floral identity & [103] \\
\hline OsMADS18 & LOC_Os07g41370 & Flowering activator & [112] \\
\hline OsMADS25 & LOC_Os04g23910 & OsMADS25 overexpression results in more lateral roots & [29] \\
\hline OsMADS26 & LOC_Os08g02070 & Expressed in rice leaves and inflorescences & [165] \\
\hline OsMADS27 & LOC_Os02g36924 & Produced more lateral roots & [50] \\
\hline OsMADS29 & LOC_Os02g07430 & $\begin{array}{l}\text { Involved in programmed cell death (PCD) in the developing embryonic } \\
\text { cell nuclear region }\end{array}$ & {$[166,167]$} \\
\hline OsMADS34 & LOC_Os03g54170 & Involved in development of the inflorescence & [152] \\
\hline OsMADS50 & LOC_Os03g03100 & Flowering activator & [107] \\
\hline OsMADS51 & LOC_Os01g69850 & Flowering activator & [113] \\
\hline OsMADS56 & LOC_Os10g39130 & Flowering suppressor & [107] \\
\hline OsMADS57 & LOC_Os02g49840 & Expressed in root vasculature & {$[35,44]$} \\
\hline OsMADS61 & LOC_Os04g38770 & Expressed in root vasculature & {$[35,44]$} \\
\hline OsMADS62 & LOC_Os08g38590 & Rice anther development & [168] \\
\hline OsMADS63 & LOC_Os06g11970 & Rice anther development & [168] \\
\hline OsMADS68 & LOC_Os11g43740 & Pollen development & [153] \\
\hline OsMADS77 & LOC_Os09g02780 & Endosperm development & [169] \\
\hline OsMADS87 & LOC_Os03g38610 & Endosperm development & [170] \\
\hline OsMADS89 & LOC_Os01g18440 & Endosperm development & {$[170]$} \\
\hline
\end{tabular}

\section{MADS-Box Genes Play an Important Role in Seed Setting and Development}

There are several key reproductive phases in the life cycle of an angiosperm that lead to sufficient seed setting. Pollination and subsequent fertilization of the ovules in the flower are key events to produce viable seeds. A large number of MADS-box mutants in flowering plant species implies that members of this gene family perform important regulatory functions in diverse conditions during seed development [34,171]. AGL21 inhibits seed germination in Arabidopsis under osmotic stress conditions in addition to its function in lateral root development [172]. Seeds of AGL21 loss-of-function lines germinate at a lower rate than wild-type plants under salt stress $(150 \mathrm{mM} \mathrm{NaCl})$, severe osmotic stress $(300 \mathrm{mM}$ mannitol), and ABA treatment. AGL21 controls the activity of $A B I 5$, which is required for ABA signaling, and ABI5 is required for AGL21-regulated seed germination. AGL15 is involved in seed formation, and overexpression lines show delayed silique maturity and seed desiccation [14]. 
In the rice genome, the MADS-box genes are members of a large TF family containing almost 75 members [103]. The majority have reported involvement in floral organ development, and some are important for endosperm development $[63,173]$. For example, OsMADS29 is involved in seed development [166,167,174]; OsMADS87 is involved in endosperm cellularization and seed size regulation [175]. Heat treatment (from moderate to severe) for $48 \mathrm{~h}$ after fertilization reduces the expression of three rice MADS-box genes, OsMADS82, OsMADS87, and OsMADS89, leading to reduced size and viability of rice seeds [175]. This observation led researchers to investigate OsMADS87 in mutant rice lines [175]. They discovered that RNAi lines maintained under ideal conditions showed increased endosperm cellularization (the process during which the endosperm exits the multi-nucleate stage and initiates cytokinesis) and decreased grain size due to reduced OsMADS87 expression. However, OsMADS87 overexpression was found to have no effect on endosperm cellularization but resulted in larger mature seeds. When heat-stressed plants $\left(35^{\circ} \mathrm{C}\right)$ were compared to control plants, the overexpression and wild-type lines had smaller seeds, but the RNAi lines were unaffected. It has also been reported that OsMADS87 expression is temperature sensitive and negatively associated with increased expression of OSFIE1, the only PRC2 complex member with heat sensitivity in ripening rice seeds [176]. The Arabidopsis homolog PHE1 is responsible for early endosperm development, although its role in seed size development is unknown. Moreover, rice plants with both stable amylose concentration at high temperatures and spikelet fertility can be obtained by inhibiting OsMADS7 function during endosperm development [163]. These findings suggest that OsMADS7 is a promising candidate gene for maintaining stable amylose contents in rice at high temperatures. Specifically reducing the expression of OsMADS7 during rice endosperm formation may be an effective strategy for breeding high-quality rice that is tolerant of temperature stress.

Several key genes are expressed in Arabidopsis during seed development. AGL62 controls the timing of endosperm cellularization; this process occurs prematurely in lossof-function of agl62 mutants, limiting normal embryo development [89]. AGL23 has been linked to the formation of both female gametophytes and seeds. After megasporogenesis, agl23 mutant ovules are partially inhibited, implying that AGL23 plays a function in early embryo sac development [87]. AGL28 is a unique type I MADS-box gene because, in addition to the embryo sac development, it is expressed in a variety of organs during seed development [88].

It is worth mentioning that B-sister genes, a novel collection of MIKC MADS-box genes, are close relatives of B-type genes [31]. B-sister proteins are found in both gymnosperm and angiosperm species [166,177-179]. B-sister genes are important for ovule and seed establishment in Arabidopsis [31,180,181]. An Arabidopsis B-sister gene, ARABIDOPSIS $B S I S T E R(A B S)$, controls endothelial growth and proanthocyanidin (PA) accumulation in the seed coat [181-183]. GORDITA (GOA), another Arabidopsis B-sister gene, regulates ovule coat production and fruit longitudinal development in a novel and non-redundant manner [184].

The MADS-domain TF STK is involved in ovule identity determination [183] and transmission tract development $[185,186]$, and also plays a pivotal role in seed abscission $[187,188]$. The stk mutants are reported to have smaller seeds compared with wild-type plants [19]. STK increases cell cycle progression in seeds via E2Fa, a pathway that is considered critical for seed size regulation [189]. It has also been reported that STK is necessary for endothelium differentiation in conjunction with $A B S$ [181]. In Arabidopsis thaliana, mutations in XYLOSIDASE1 (XYL1) have a significant impact on seed germination, seed size, and fruit development. The MADS-box TF STK regulates XYL1 expression, which is directly involved in developing seeds and fruit [190]. Figure 2 includes several MADS-box genes responsible for root, seedling, flowering, ovule, and pollen grain development of rice. 


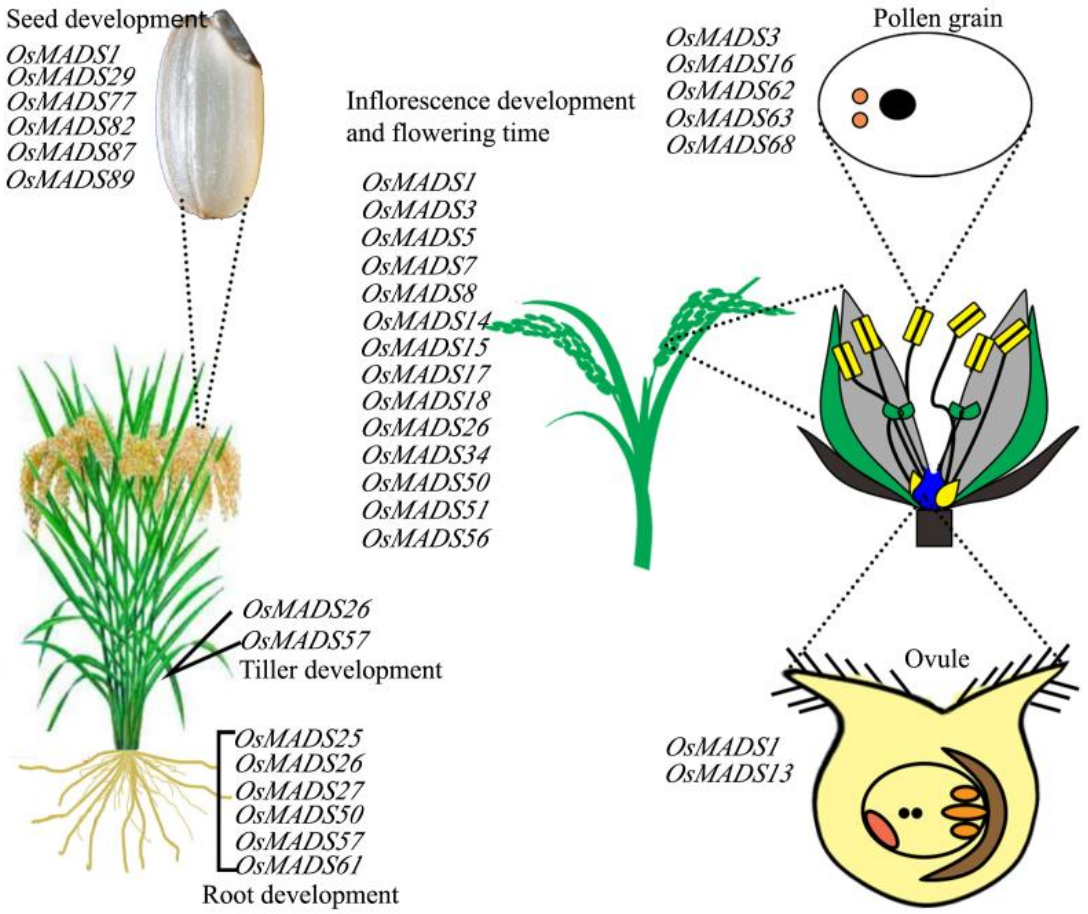

Figure 2. The biological roles of MADS-box genes in controlling the development of various vegetative and reproductive structures in the rice plant. Many MADS-box genes mediate the transition to flowering induction (e.g., OsMADS1 [161], OsMADS3 [147], OsMADS5 [162], OsMADS7 [163], OsMADS8 [152], OsMADS14 [112], OsMADS15 [112], OsMADS17 [103], OsMADS18 [112], OsMADS26 [165], OsMADS34 [152], OsMADS50 [107], OsMADS51 [113], and OsMADS56 [107]). MADS-box genes involved in tiller development include OsMADS26 [191] and OsMADS57 [50]. Those involved in root development include OsMADS25 [44], OsMADS26 [191], OsMADS27 [50], OsMADS50 [49], OsMADS57, and OsMADS61 [38,44]; in ovule growth, OsMADS1 [161] and OsMADS13 [148]; in pollen grain maturation, OsMADS3 [147], OsMADS16 [164], OsMADS62, OsMADS63 [168], and OsMADS68 [153]; and in seed and endosperm development, OsMADS1 [161], OsMADS29 [166,167,174], OsMADS77 [169], OsMADS82 [175], OsMADS87 [170,175], and OsMADS89 [170,175].

\section{Concluding Remarks and Future Perspectives}

Alterations in gene regulation are one of the most significant routes leading to phenotypic changes. Due to their capacity to affect gene expression, TFs can cause developmental shifts. TFs have also been shown to function in regulating responses to environmental stress throughout the plant life cycle. Furthermore, small changes in the expression of a few key TFs have been shown to impact the development of numerous processes and structures. Specific mutants have shown that TFs from the MADS-box gene family are important regulators of Arabidopsis development at all growth stages. Multiple studies have also shown that MADS-box genes play important roles in controlling plant responses and tolerance to a wide variety of abiotic stimuli, highlighting their relevance as integrators of environmental signals and endogenous hormones in a taxonomically diverse range of plant species.

Several functional investigations have been undertaken into the developmental roles of MADS-box genes in rice; however, a great deal remains unknown. Gene knockdown mutants (single and higher-order) should be identified to expose the functional characteristics of MADS-box genes throughout the development of rice plants. In addition, the interactions of MADS-domain proteins with other proteins will aid in determining the molecular functions of MADS-box genes in rice. The functional diversification process of duplicated MADS-box genes, including OsMADS2, OsMADS3, OsMADS4, and OsMADS58, should 
also be addressed. Such an investigation, along with analogous observations in other grass species, will contribute to the understanding of how grass flowers and inflorescences evolved and diversified.

The significance of MADS-box genes has mainly been investigated in the model plant Arabidopsis thaliana. The literature reviewed here, however, demonstrates that our understanding is quickly evolving with respect to MADS-box genes that govern flower development in rice due to the novel functional genomics methods now possible. The rapid advances in this area were primarily a result of knowledge gained in Arabidopsis [192]. Many mutant populations based on transposons and T-DNA insertions are accessible for functional investigations of rice genes [193,194]. CRISPR-Cas9 systems have been widely exploited today as tools for genome editing in a variety of plant species $[195,196]$. A technique that uses chemical mutagens such as ethyl methanesulfonate (EMS) can also be used to study gene function via reverse genetics [197-199].

Author Contributions: Conceptualization, L.S., A.S. and R.A.; supervision, W.W., L.C. and S.C.; writing original draft, L.S.; writing-review and editing, L.S. and W.W. All authors have read and agreed to the published version of the manuscript.

Funding: This work was funded by the National Natural Science Foundation of China (grant numbers 31871604, 32071996, and 31961143016), the Fundamental Research Funds of Central Public Welfare Research Institutions (grant number CPSIBRF-CNRRI-202102), the Agricultural Science and Technology Innovation Program of the Chinese Academy of Agricultural Sciences (grant number CAAS-ASTIP2013-CNRRI), and Hainan Yazhou Bay Seed Lab (grant number B21HJ0219).

Data Availability Statement: Not applicable.

Acknowledgments: Not applicable.

Conflicts of Interest: The authors declare no conflict of interest.

\section{References}

1. Schilling, S.; Pan, S.; Kennedy, A.; Melzer, R. MADS-box genes and crop domestication: The jack of all traits. J. Exp. Bot. 2018, 69, 1447-1469. [CrossRef]

2. Ma, J.; Yang, Y.; Luo, W.; Yang, C.; Ding, P.; Liu, Y.; Qiao, L.; Chang, Z.; Geng, H.; Wang, P. Genome-wide identification and analysis of the MADS-box gene family in bread wheat (Triticum aestivum L.). PLoS ONE 2017, 12, e0181443. [CrossRef] [PubMed]

3. De Bodt, S.; Raes, J.; Van de Peer, Y.; Theißen, G. And then there were many: MADS goes genomic. Trends Plant Sci. 2003, 8, 475-483. [CrossRef]

4. Theißen, G.; Kim, J.T.; Saedler, H. Classification and phylogeny of the MADS-box multigene family suggest defined roles of MADS-box gene subfamilies in the morphological evolution of eukaryotes. J. Mol. Evol. 1996, 43, 484-516. [CrossRef] [PubMed]

5. Agarwal, P.; Khurana, P. Overexpression of TaMADS from wheat promotes flowering by upregulating expression of floral promoters and provides protection against thermal stress. Plant Gene 2019, 17, 100168. [CrossRef]

6. Masiero, S.; Colombo, L.; Grini, P.E.; Schnittger, A.; Kater, M.M. The emerging importance of type I MADS box transcription factors for plant reproduction. Plant Cell 2011, 23, 865-872. [CrossRef]

7. Kaufmann, K.; Melzer, R.; Theißen, G. MIKC-type MADS-domain proteins: Structural modularity, protein interactions and network evolution in land plants. Gene 2005, 347, 183-198. [CrossRef]

8. Masiero, S.; Imbriano, C.; Ravasio, F.; Favaro, R.; Pelucchi, N.; Gorla, M.S.; Mantovani, R.; Colombo, L.; Kater, M.M. Ternary complex formation between MADS-box transcription factors and the histone fold protein NF-YB. J. Biol. Chem. 2002, 277, 26429-26435. [CrossRef]

9. Yang, Y.; Fanning, L.; Jack, T. The K domain mediates heterodimerization of the Arabidopsis floral organ identity proteins, APETALA3 and PISTILLATA. Plant J. 2003, 33, 47-59. [CrossRef]

10. Van Dijk, A.D.; Morabito, G.; Fiers, M.; van Ham, R.C.; Angenent, G.C.; Immink, R.G. Sequence motifs in MADS transcription factors responsible for specificity and diversification of protein-protein interaction. PLoS Comput. Biol. 2010, 6, e1001017. [CrossRef]

11. Callens, C.; Tucker, M.R.; Zhang, D.; Wilson, Z.A. Dissecting the role of MADS-box genes in monocot floral development and diversity. J. Exp. Bot. 2018, 69, 2435-2459. [CrossRef] [PubMed]

12. Ito, Y.; Kitagawa, M.; Ihashi, N.; Yabe, K.; Kimbara, J.; Yasuda, J.; Ito, H.; Inakuma, T.; Hiroi, S.; Kasumi, T. DNA-binding specificity, transcriptional activation potential, and the rin mutation effect for the tomato fruit-ripening regulator RIN. Plant $J$. 2008, 55, 212-223. [CrossRef] [PubMed]

13. Favaro, R.; Pinyopich, A.; Battaglia, R.; Kooiker, M.; Borghi, L.; Ditta, G.; Yanofsky, M.F.; Kater, M.M.; Colombo, L. MADS-box protein complexes control carpel and ovule development in Arabidopsis. Plant Cell 2003, 15, 2603-2611. [CrossRef] 
14. Fang, S.-C.; Fernandez, D.E. Effect of regulated overexpression of the MADS domain factor AGL15 on flower senescence and fruit maturation. Plant Physiol. 2002, 130, 78-89. [CrossRef]

15. Benedito, V.; Angenent, G.; Van Tuyl, J.; Krens, F. Lilium longiflorum and molecular floral development: The ABCDE model. In Proceedings of the XXI International Eucarpia Symposium on Classical versus Molecular Breeding of Ornamentals-Part II 651, Munich, Germany, 25-29 August 2003; pp. 83-89.

16. Kater, M.M.; Dreni, L.; Colombo, L. Functional conservation of MADS-box factors controlling floral organ identity in rice and Arabidopsis. J. Exp. Bot. 2006, 57, 3433-3444. [CrossRef] [PubMed]

17. Pelaz, S.; Ditta, G.S.; Baumann, E.; Wisman, E.; Yanofsky, M.F. B and C floral organ identity functions require SEPALLATA MADS-box genes. Nature 2000, 405, 200-203. [CrossRef]

18. Coen, E.S.; Meyerowitz, E.M. The war of the whorls: Genetic interactions controlling flower development. Nature 1991, 353, 31-37. [CrossRef]

19. Pinyopich, A.; Ditta, G.S.; Savidge, B.; Liljegren, S.J.; Baumann, E.; Wisman, E.; Yanofsky, M.F. Assessing the redundancy of MADS-box genes during carpel and ovule development. Nature 2003, 424, 85-88. [CrossRef]

20. Thei, G.; Saedler, H. Plant biology: Floral quartets. Nature 2001, 409, 469-472.

21. Ditta, G.; Pinyopich, A.; Robles, P.; Pelaz, S.; Yanofsky, M.F. The SEP4 gene of Arabidopsis thaliana functions in floral organ and meristem identity. Curr. Biol. 2004, 14, 1935-1940. [CrossRef]

22. Smaczniak, C.; Immink, R.G.; Angenent, G.C.; Kaufmann, K. Developmental and evolutionary diversity of plant MADS-domain factors: Insights from recent studies. Development 2012, 139, 3081-3098. [CrossRef] [PubMed]

23. Yan, W.; Chen, D.; Kaufmann, K. Molecular mechanisms of floral organ specification by MADS domain proteins. Curr. Opin. Plant Biol. 2016, 29, 154-162. [CrossRef] [PubMed]

24. Bartlett, M.E. Changing MADS-box transcription factor protein-protein interactions as a mechanism for generating floral morphological diversity. Integr. Comp. Biol. 2017, 57, 1312-1321. [CrossRef] [PubMed]

25. Bloomer, R.; Dean, C. Fine-tuning timing: Natural variation informs the mechanistic basis of the switch to flowering in Arabidopsis thaliana. J. Exp. Bot. 2017, 68, 5439-5452. [CrossRef] [PubMed]

26. Whittaker, C.; Dean, C. The FLC locus: A platform for discoveries in epigenetics and adaptation. Annu. Rev. Cell Dev. Biol. 2017, 33, 555-575. [CrossRef]

27. Theißen, G.; Rümpler, F.; Gramzow, L. Array of MADS-box genes: Facilitator for rapid adaptation? Trends Plant Sci. 2018, 23, 563-576. [CrossRef]

28. Theißen, G.; Melzer, R.; Rümpler, F. MADS-domain transcription factors and the floral quartet model of flower development: Linking plant development and evolution. Development 2016, 143, 3259-3271. [CrossRef]

29. Yu, C.; Liu, Y.; Zhang, A.; Su, S.; Yan, A.; Huang, L.; Ali, I.; Liu, Y.; Forde, B.G.; Gan, Y. MADS-box transcription factor OsMADS25 regulates root development through affection of nitrate accumulation in rice. PLoS ONE 2015, 10, e0135196. [CrossRef]

30. Rounsley, S.D.; Ditta, G.S.; Yanofsky, M.F. Diverse roles for MADS box genes in Arabidopsis development. Plant Cell 1995, 7, 1259-1269.

31. Becker, A.; Theißen, G. The major clades of MADS-box genes and their role in the development and evolution of flowering plants. Mol. Phylogenet. Evol. 2003, 29, 464-489. [CrossRef]

32. Alvarez-Buylla, E.R.; García-Ponce, B.; Sánchez, M.d.1.P.; Espinosa-Soto, C.; García-Gómez, M.L.; Piñeyro-Nelson, A.; GarayArroyo, A. MADS-box genes underground becoming mainstream: Plant root developmental mechanisms. New Phytol. 2019, 223, 1143-1158. [CrossRef] [PubMed]

33. Zhang, H.; Forde, B.G. An Arabidopsis MADS box gene that controls nutrient-induced changes in root architecture. Science 1998, 279, 407-409. [CrossRef] [PubMed]

34. Alvarez-Buylla, E.R.; Liljegren, S.J.; Pelaz, S.; Gold, S.E.; Burgeff, C.; Ditta, G.S.; Vergara-Silva, F.; Yanofsky, M.F. MADS-box gene evolution beyond flowers: Expression in pollen, endosperm, guard cells, roots and trichomes. Plant J. 2000, 24, 457-466. [CrossRef] [PubMed]

35. Yu, C.; Su, S.; Xu, Y.; Zhao, Y.; Yan, A.; Huang, L.; Ali, I.; Gan, Y. The effects of fluctuations in the nutrient supply on the expression of five members of the AGL17 clade of MADS-box genes in rice. PLoS ONE 2014, 9, e105597. [CrossRef] [PubMed]

36. Gan, Y.; Filleur, S.; Rahman, A.; Gotensparre, S.; Forde, B.G. Nutritional regulation of ANR1 and other root-expressed MADS-box genes in Arabidopsis thaliana. Planta 2005, 222, 730-742. [CrossRef] [PubMed]

37. Gan, Y.; Bernreiter, A.; Filleur, S.; Abram, B.; Forde, B.G. Overexpressing the ANR1 MADS-box gene in transgenic plants provides new insights into its role in the nitrate regulation of root development. Plant Cell Physiol. 2012, 53, 1003-1016. [CrossRef] [PubMed]

38. Yu, L.-H.; Miao, Z.-Q.; Qi, G.-F.; Wu, J.; Cai, X.-T.; Mao, J.-L.; Xiang, C.-B. MADS-box transcription factor AGL21 regulates lateral root development and responds to multiple external and physiological signals. Mol. Plant 2014, 7, 1653-1669. [CrossRef]

39. Remans, T.; Nacry, P.; Pervent, M.; Filleur, S.; Diatloff, E.; Mounier, E.; Tillard, P.; Forde, B.G.; Gojon, A. The Arabidopsis NRT1. 1 transporter participates in the signaling pathway triggering root colonization of nitrate-rich patches. Proc. Natl. Acad. Sci. USA 2006, 103, 19206-19211. [CrossRef]

40. Yan, Y.; Wang, H.; Hamera, S.; Chen, X.; Fang, R. miR444a has multiple functions in the rice nitrate-signaling pathway. Plant J. 2014, 78, 44-55. [CrossRef] 
41. Zhao, P.X.; Zhang, J.; Chen, S.Y.; Wu, J.; Xia, J.Q.; Sun, L.Q.; Ma, S.S.; Xiang, C.B. Arabidopsis MADS-box factor AGL16 is a negative regulator of plant response to salt stress by downregulating salt-responsive genes. New Phytol. 2021, 232, 2418-2439. [CrossRef]

42. Nawy, T.; Lee, J.-Y.; Colinas, J.; Wang, J.Y.; Thongrod, S.C.; Malamy, J.E.; Birnbaum, K.; Benfey, P.N. Transcriptional profile of the Arabidopsis root quiescent center. Plant Cell 2005, 17, 1908-1925. [CrossRef] [PubMed]

43. Hacham, Y.; Holland, N.; Butterfield, C.; Ubeda-Tomas, S.; Bennett, M.J.; Chory, J.; Savaldi-Goldstein, S. Brassinosteroid perception in the epidermis controls root meristem size. Development 2011, 138, 839-848. [CrossRef] [PubMed]

44. Puig, J.; Meynard, D.; Khong, G.N.; Pauluzzi, G.; Guiderdoni, E.; Gantet, P. Analysis of the expression of the AGL17-like clade of MADS-box transcription factors in rice. Gene Expr. Patterns 2013, 13, 160-170. [CrossRef] [PubMed]

45. Zhang, G.; Xu, N.; Chen, H.; Wang, G.; Huang, J. OsMADS25 regulates root system development via auxin signalling in rice. Plant J. 2018, 95, 1004-1022. [CrossRef]

46. Huang, S.; Liang, Z.; Chen, S.; Sun, H.; Fan, X.; Wang, C.; Xu, G.; Zhang, Y. A transcription factor, OsMADS57, regulates long-distance nitrate transport and root elongation. Plant Physiol. 2019, 180, 882-895. [CrossRef]

47. Jia, Z.; von Wirén, N. Signaling pathways underlying nitrogen-dependent changes in root system architecture: From model to crop species. J. Exp. Bot. 2020, 71, 4393-4404. [CrossRef]

48. $\mathrm{Wu}, \mathrm{J} . ; \mathrm{Yu}, \mathrm{C}$; Huang, L.; Gan, Y. A rice transcription factor, OsMADS57, positively regulates high salinity tolerance in transgenic Arabidopsis thaliana and Oryza sativa plants. Physiol. Plant. 2021, 173, 1120-1135. [CrossRef]

49. Shao, Y.; Zhou, H.-Z.; Wu, Y.; Zhang, H.; Lin, J.; Jiang, X.; He, Q.; Zhu, J.; Li, Y.; Yu, H. OsSPL3, an SBP-domain protein, regulates crown root development in rice. Plant Cell 2019, 31, 1257-1275. [CrossRef]

50. Chen, H.; Xu, N.; Wu, Q.; Yu, B.; Chu, Y.; Li, X.; Huang, J.; Jin, L. OsMADS27 regulates the root development in a NO3-Dependent manner and modulates the salt tolerance in rice (Oryza sativa L.). Plant Sci. 2018, 277, 20-32. [CrossRef]

51. Duan, K.; Li, L.; Hu, P.; Xu, S.P.; Xu, Z.H.; Xue, H.W. A brassinolide-suppressed rice MADS-box transcription factor, OsMDP1, has a negative regulatory role in BR signaling. Plant J. 2006, 47, 519-531. [CrossRef]

52. Lee, S.; Woo, Y.-M.; Ryu, S.-I.; Shin, Y.-D.; Kim, W.T.; Park, K.Y.; Lee, I.-J.; An, G. Further characterization of a rice AGL12 group MADS-box gene, OsMADS26. Plant Physiol. 2008, 147, 156-168. [CrossRef] [PubMed]

53. Hu, F.; Wang, D.; Zhao, X.; Zhang, T.; Sun, H.; Zhu, L.; Zhang, F.; Li, L.; Li, Q.; Tao, D. Identification of rhizome-specific genes by genome-wide differential expression analysis in Oryza longistaminata. BMC Plant Biol. 2011, 11, 1-14. [CrossRef] [PubMed]

54. Krugman, T.; Peleg, Z.; Quansah, L.; Chagué, V.; Korol, A.B.; Nevo, E.; Saranga, Y.; Fait, A.; Chalhoub, B.; Fahima, T. Alteration in expression of hormone-related genes in wild emmer wheat roots associated with drought adaptation mechanisms. Funct. Integr. Genom. 2011, 11, 565-583. [CrossRef]

55. Lee, S.; Choi, S.C.; An, G. Rice SVP-group MADS-box proteins, OsMADS22 and OsMADS55, are negative regulators of brassinosteroid responses. Plant J. 2008, 54, 93-105. [CrossRef] [PubMed]

56. Liu, S.; Ma, T.; Ma, L.; Lin, X. Ectopic expression of PvSOC1, a homolog of SOC1 from Phyllostachys violascens, promotes flowering in Arabidopsis and rice. Acta Physiol. Plant. 2016, 38, 1-9. [CrossRef]

57. Aceto, S.; Gaudio, L. The MADS and the beauty: Genes involved in the development of orchid flowers. Curr. Genom. 2011, 12, 342-356. [CrossRef]

58. Claßen-Bockhoff, R.; Bull-Hereñu, K. Towards an ontogenetic understanding of inflorescence diversity. Ann. Bot. 2013, 112, 1523-1542. [CrossRef]

59. Kaufmann, K.; Wellmer, F.; Muiño, J.M.; Ferrier, T.; Wuest, S.E.; Kumar, V.; Serrano-Mislata, A.; Madueno, F.; Krajewski, P.; Meyerowitz, E.M. Orchestration of floral initiation by APETALA1. Science 2010, 328, 85-89. [CrossRef]

60. Moyroud, E.; Minguet, E.G.; Ott, F.; Yant, L.; Posé, D.; Monniaux, M.; Blanchet, S.; Bastien, O.; Thévenon, E.; Weigel, D. Prediction of regulatory interactions from genome sequences using a biophysical model for the Arabidopsis LEAFY transcription factor. Plant Cell 2011, 23, 1293-1306. [CrossRef]

61. Winter, C.M.; Austin, R.S.; Blanvillain-Baufumé, S.; Reback, M.A.; Monniaux, M.; Wu, M.-F.; Sang, Y.; Yamaguchi, A.; Yamaguchi, N.; Parker, J.E. LEAFY target genes reveal floral regulatory logic, cis motifs, and a link to biotic stimulus response. Dev. Cell 2011, 20, 430-443. [CrossRef]

62. Ferrándiz, C.; Gu, Q.; Martienssen, R.; Yanofsky, M.F. Redundant regulation of meristem identity and plant architecture by FRUITFULL, APETALA1 and CAULIFLOWER. Development 2000, 127, 725-734. [CrossRef] [PubMed]

63. Liu, C.; Teo, Z.W.N.; Bi, Y.; Song, S.; Xi, W.; Yang, X.; Yin, Z.; Yu, H. A conserved genetic pathway determines inflorescence architecture in Arabidopsis and rice. Dev. Cell 2013, 24, 612-622. [CrossRef]

64. Goslin, K.; Zheng, B.; Serrano-Mislata, A.; Rae, L.; Ryan, P.T.; Kwaśniewska, K.; Thomson, B.; Ó’Maoiléidigh, D.S.; Madueño, F.; Wellmer, F.; et al. Transcription factor interplay between LEAFY and APETALA1/CAULIFLOWER during floral initiation. Physiol. Plant. 2017, 174, 1097-1109. [CrossRef] [PubMed]

65. Pajoro, A.; Madrigal, P.; Muiño, J.M.; Matus, J.T.; Jin, J.; Mecchia, M.A.; Debernardi, J.M.; Palatnik, J.F.; Balazadeh, S.; Arif, M. Dynamics of chromatin accessibility and gene regulation by MADS-domain transcription factors in flower development. Genome Biol. 2014, 15, 1-19. [CrossRef]

66. Winter, C.M.; Yamaguchi, N.; Wu, M.F.; Wagner, D. Transcriptional programs regulated by both LEAFY and APETALA1 at the time of flower formation. Physiol. Plant. 2015, 155, 55-73. [CrossRef] 
67. Yamaguchi, A.; Wu, M.F.; Yang, L.; Wu, G.; Poethig, R.S.; Wagner, D. The microRNA-regulated SBP-Box transcription factor SPL3 is a direct upstream activator of LEAFY, FRUITFULL, and APETALA1. Dev. cell 2009, 17, 268-278. [CrossRef]

68. Nakagawa, M.; Shimamoto, K.; Kyozuka, J. Overexpression of RCN1 and RCN2, rice TERMINAL FLOWER 1/CENTRORADIALIS homologs, confers delay of phase transition and altered panicle morphology in rice. Plant J. 2002, 29, 743-750. [CrossRef] [PubMed]

69. Carmona, M.J.; Calonje, M.; Martínez-Zapater, J.M. The FT /TFL1 gene family in grapevine. Plant Mol. Biol. 2007, 63, 637-650. [CrossRef] [PubMed]

70. Danilevskaya, O.N.; Meng, X.; Ananiev, E.V. Concerted modification of flowering time and inflorescence architecture by ectopic expression of TFL1-like genes in maize. Plant Physiol. 2010, 153, 238-251. [CrossRef] [PubMed]

71. Zhang, S.; Hu, W.; Wang, L.; Lin, C.; Cong, B.; Sun, C.; Luo, D. TFL1/CEN-like genes control intercalary meristem activity and phase transition in rice. Plant Sci. 2005, 168, 1393-1408. [CrossRef]

72. Meng, Q.; Li, X.; Zhu, W.; Yang, L.; Liang, W.; Dreni, L.; Zhang, D. Regulatory network and genetic interactions established by OsMADS34 in rice inflorescence and spikelet morphogenesis. J. Integr. Plant Biol. 2017, 59, 693-707. [CrossRef] [PubMed]

73. Tapia-López, R.; García-Ponce, B.; Dubrovsky, J.G.; Garay-Arroyo, A.; Pérez-Ruíz, R.V.; Kim, S.-H.; Acevedo, F.; Pelaz, S.; Alvarez-Buylla, E.R. An AGAMOUS-related MADS-box gene, XAL1 (AGL12), regulates root meristem cell proliferation and flowering transition in Arabidopsis. Plant Physiol. 2008, 146, 1182-1192. [CrossRef] [PubMed]

74. Fernandez, D.E.; Heck, G.R.; Perry, S.E.; Patterson, S.E.; Bleecker, A.B.; Fang, S.-C. The embryo MADS domain factor AGL15 acts postembryonically: Inhibition of perianth senescence and abscission via constitutive expression. Plant Cell 2000, 12, 183-197. [CrossRef] [PubMed]

75. Heck, G.R.; Perry, S.E.; Nichols, K.W.; Fernandez, D.E. AGL15, a MADS domain protein expressed in developing embryos. Plant Cell 1995, 7, 1271-1282. [PubMed]

76. Harding, E.W.; Tang, W.; Nichols, K.W.; Fernandez, D.E.; Perry, S.E. Expression and maintenance of embryogenic potential is enhanced through constitutive expression of AGAMOUS-Like 15. Plant Physiol. 2003, 133, 653-663. [CrossRef]

77. Adamczyk, B.J.; Lehti-Shiu, M.D.; Fernandez, D.E. The MADS domain factors AGL15 and AGL18 act redundantly as repressors of the floral transition in Arabidopsis. Plant J. 2007, 50, 1007-1019. [CrossRef]

78. Kutter, C.; Schoöb, H.; Stadler, M.; Meins, F., Jr.; Si-Ammour, A. MicroRNA-mediated regulation of stomatal development in Arabidopsis. Plant Cell 2007, 19, 2417-2429. [CrossRef]

79. Han, P.; García-Ponce, B.; Fonseca-Salazar, G.; Alvarez-Buylla, E.R.; Yu, H. AGAMOUS-LIKE 17, a novel flowering promoter, acts in a FT-independent photoperiod pathway. Plant J. 2008, 55, 253-265. [CrossRef]

80. Yoo, S.K.; Wu, X.; Lee, J.S.; Ahn, J.H. AGAMOUS-LIKE 6 is a floral promoter that negatively regulates the FLC/MAF clade genes and positively regulates $F T$ in Arabidopsis. Plant J. 2011, 65, 62-76. [CrossRef]

81. Chiang, G.C.; Barua, D.; Kramer, E.M.; Amasino, R.M.; Donohue, K. Major flowering time gene, FLOWERING LOCUS C, regulates seed germination in Arabidopsis thaliana. Proc. Natl. Acad. Sci. USA 2009, 106, 11661-11666. [CrossRef]

82. Deng, W.; Ying, H.; Helliwell, C.A.; Taylor, J.M.; Peacock, W.J.; Dennis, E.S. FLOWERING LOCUS C (FLC) regulates development pathways throughout the life cycle of Arabidopsis. Proc. Natl. Acad. Sci. USA 2011, 108, 6680-6685. [CrossRef]

83. Ratcliffe, O.J.; Kumimoto, R.W.; Wong, B.J.; Riechmann, J.L. Analysis of the Arabidopsis MADS AFFECTING FLOWERING gene family: MAF2 prevents vernalization by short periods of cold. Plant Cell 2003, 15, 1159-1169. [CrossRef]

84. Schönrock, N.; Bouveret, R.; Leroy, O.; Borghi, L.; Köhler, C.; Gruissem, W.; Hennig, L. Polycomb-group proteins repressthe floral activator AGL19 in the FLC-independent vernalization pathway. Genes Dev. 2006, 20, 1667-1678. [CrossRef] [PubMed]

85. Melzer, S.; Lens, F.; Gennen, J.; Vanneste, S.; Rohde, A.; Beeckman, T. Flowering-time genes modulate meristem determinacy and growth form in Arabidopsis thaliana. Nat. Genet. 2008, 40, 1489-1492. [CrossRef]

86. Michaels, S.D.; Ditta, G.; Gustafson-Brown, C.; Pelaz, S.; Yanofsky, M.; Amasino, R.M. AGL24 acts as a promoter of flowering in Arabidopsis and is positively regulated by vernalization. Plant J. 2003, 33, 867-874. [CrossRef] [PubMed]

87. Colombo, M.; Masiero, S.; Vanzulli, S.; Lardelli, P.; Kater, M.M.; Colombo, L. AGL23, a type I MADS-box gene that controls female gametophyte and embryo development in Arabidopsis. Plant J. 2008, 54, 1037-1048. [CrossRef] [PubMed]

88. Yoo, S.K.; Lee, J.S.; Ahn, J.H. Overexpression of AGAMOUS-LIKE 28 (AGL28) promotes flowering by upregulating expression of floral promoters within the autonomous pathway. Biochem. Biophys. Res. Commun. 2006, 348, 929-936. [CrossRef]

89. Kang, I.-H.; Steffen, J.G.; Portereiko, M.F.; Lloyd, A.; Drews, G.N. The AGL62 MADS domain protein regulates cellularization during endosperm development in Arabidopsis. Plant Cell 2008, 20, 635-647. [CrossRef]

90. Sridhar, V.; Shankar, V.G.; Sujatha, M.; Suman, A. Genetic control of floral transition in cereals. Indian J. Plant Genet. Resour. 2008, $21,1-16$.

91. Weigel, D. Genetic hierarchy controlling flower development. Mol. Basis Morphog. 1993, 93-107.

92. Schmid, M.; Uhlenhaut, N.H.; Godard, F.; Demar, M.; Bressan, R.; Weigel, D.; Lohmann, J.U. Dissection of floral induction pathways using global expression analysis. Development 2003, 130, 6001-6012. [CrossRef] [PubMed]

93. Lal, S.; Pacis, L.B.; Smith, H.M. Regulation of the SQUAMOSA PROMOTER-BINDING PROTEIN-LIKE genes/microRNA156 module by the homeodomain proteins PENNYWISE and POUND-FOOLISH in Arabidopsis. Mol. Plant 2011, 4, 1123-1132. [CrossRef] [PubMed]

94. Jung, J.H.; Ju, Y.; Seo, P.J.; Lee, J.H.; Park, C.M. The SOC1-SPL module integrates photoperiod and gibberellic acid signals to control flowering time in Arabidopsis. Plant J. 2012, 69, 577-588. [CrossRef] 
95. Torti, S.; Fornara, F.; Vincent, C.; Andrés, F.; Nordström, K.; Göbel, U.; Knoll, D.; Schoof, H.; Coupland, G. Analysis of the Arabidopsis shoot meristem transcriptome during floral transition identifies distinct regulatory patterns and a leucine-rich repeat protein that promotes flowering. Plant Cell 2012, 24, 444-462. [CrossRef] [PubMed]

96. Gu, X.; Wang, Y.; He, Y. Photoperiodic regulation of flowering time through periodic histone deacetylation of the florigen gene FT. PLoS Biol. 2013, 11, e1001649. [CrossRef]

97. Fernandez, D.E.; Wang, C.-T.; Zheng, Y.; Adamczyk, B.J.; Singhal, R.; Hall, P.K.; Perry, S.E. The MADS-domain factors AGAMOUSLIKE15 and AGAMOUS-LIKE18, along with SHORT VEGETATIVE PHASE and AGAMOUS-LIKE24, are necessary to block floral gene expression during the vegetative phase. Plant Physiol. 2014, 165, 1591-1603. [CrossRef] [PubMed]

98. Serivichyaswat, P.; Ryu, H.-S.; Kim, W.; Kim, S.; Chung, K.S.; Kim, J.J.; Ahn, J.H. Expression of the floral repressor miRNA156 is positively regulated by the AGAMOUS-like proteins AGL15 and AGL18. Mol. Cells 2015, 38, 259. [CrossRef]

99. Amasino, R. Seasonal and developmental timing of flowering. Plant J. 2010, 61, 1001-1013. [CrossRef]

100. Lee, J.; Lee, I. Regulation and function of SOC1, a flowering pathway integrator. J. Exp. Bot. 2010, 61, 2247-2254. [CrossRef]

101. Srikanth, A.; Schmid, M. Regulation of flowering time: All roads lead to Rome. Cell. Mol. Life Sci. 2011, 68, 2013-2037. [CrossRef]

102. Yu, S.; Galvão, V.C.; Zhang, Y.-C.; Horrer, D.; Zhang, T.-Q.; Hao, Y.-H.; Feng, Y.-Q.; Wang, S.; Schmid, M.; Wang, J.-W. Gibberellin regulates the Arabidopsis floral transition through miR156-targeted SQUAMOSA PROMOTER BINDING-LIKE transcription factors. Plant Cell 2012, 24, 3320-3332. [CrossRef] [PubMed]

103. Arora, R.; Agarwal, P.; Ray, S.; Singh, A.K.; Singh, V.P.; Tyagi, A.K.; Kapoor, S. MADS-box gene family in rice: Genome-wide identification, organization and expression profiling during reproductive development and stress. BMC Genom. 2007, 8, 1-21. [CrossRef] [PubMed]

104. Tadege, M.; Sheldon, C.C.; Helliwell, C.A.; Upadhyaya, N.M.; Dennis, E.S.; Peacock, W.J. Reciprocal control of flowering time by OsSOC1 in transgenic Arabidopsis and by FLC in transgenic rice. Plant Biotechnol. J. 2003, 1, 361-369. [CrossRef] [PubMed]

105. Lee, S.; Kim, J.; Han, J.J.; Han, M.J.; An, G. Functional analyses of the flowering time gene OsMADS50, the putative SUPPRESSOR OF OVEREXPRESSION OF CO 1/AGAMOUS-LIKE 20 (SOC1/AGL20) ortholog in rice. Plant J. 2004, 38, 754-764. [CrossRef] [PubMed]

106. Nam, J.; Kaufmann, K.; Theißen, G.; Nei, M. A simple method for predicting the functional differentiation of duplicate genes and its application to MIKC-type MADS-box genes. Nucleic Acids Res. 2005, 33, e12. [CrossRef]

107. Ryu, C.H.; Lee, S.; Cho, L.H.; Kim, S.L.; Lee, Y.S.; Choi, S.C.; Jeong, H.J.; Yi, J.; Park, S.J.; Han, C.D. OsMADS50 and OsMADS56 function antagonistically in regulating long day (LD)-dependent flowering in rice. Plant Cell Environ. 2009, 32, 1412-1427. [CrossRef]

108. Kang, H.-G.; An, G. Isolation and characterization of a rice MADS box gene belonging to the AGL2 gene family. Mol. Cells 1997, 7 , 45-51.

109. Kang, H.-G.; Jang, S.; Chung, J.-E.; Cho, Y.-G.; An, G. Characterization of two rice MADS box genes that control flowering time. Mol. Cells 1997, 7, 559-566.

110. Zhao, X.Y.; Cheng, Z.J.; Zhang, X.S. Overexpression of TaMADS1, a SEPALLATA-like gene in wheat, causes early flowering and the abnormal development of floral organs in Arabidopsis. Planta 2006, 223, 698-707. [CrossRef]

111. Su, Y.; Liu, J.; Liang, W.; Dou, Y.; Fu, R.; Li, W.; Feng, C.; Gao, C.; Zhang, D.; Kang, Z. Wheat AGAMOUS LIKE 6 transcription factors function in stamen development by regulating the expression of Ta APETALA3. Development 2019, 146, dev177527. [CrossRef]

112. Kobayashi, K.; Yasuno, N.; Sato, Y.; Yoda, M.; Yamazaki, R.; Kimizu, M.; Yoshida, H.; Nagamura, Y.; Kyozuka, J. Inflorescence meristem identity in rice is specified by overlapping functions of three AP1/FUL-like MADS box genes and PAP2, a SEPALLATA MADS box gene. Plant Cell 2012, 24, 1848-1859. [CrossRef] [PubMed]

113. Kim, S.L.; Lee, S.; Kim, H.J.; Nam, H.G.; An, G. OsMADS51 is a short-day flowering promoter that functions upstream of Ehd1, OsMADS14, and Hd3a. Plant Physiol. 2007, 145, 1484-1494. [CrossRef] [PubMed]

114. Wigge, P.A.; Kim, M.C.; Jaeger, K.E.; Busch, W.; Schmid, M.; Lohmann, J.U.; Weigel, D. Integration of spatial and temporal information during floral induction in Arabidopsis. Science 2005, 309, 1056-1059. [CrossRef] [PubMed]

115. Andrés, F.; Coupland, G. The genetic basis of flowering responses to seasonal cues. Nat. Rev. Genet. 2012, 13, 627-639. [CrossRef]

116. Samach, A.; Onouchi, H.; Gold, S.E.; Ditta, G.S.; Schwarz-Sommer, Z.; Yanofsky, M.F.; Coupland, G. Distinct roles of CONSTANS target genes in reproductive development of Arabidopsis. Science 2000, 288, 1613-1616. [CrossRef]

117. Abe, M.; Kobayashi, Y.; Yamamoto, S.; Daimon, Y.; Yamaguchi, A.; Ikeda, Y.; Ichinoki, H.; Notaguchi, M.; Goto, K.; Araki, T. FD a bZIP protein mediating signals from the floral pathway integrator FT at the shoot apex. Science 2005, 309, 1052-1056. [CrossRef]

118. Jang, S.; Torti, S.; Coupland, G. Genetic and spatial interactions between FT, TSF and SVP during the early stages of floral induction in Arabidopsis. Plant J. 2009, 60, 614-625. [CrossRef]

119. D'Aloia, M.; Bonhomme, D.; Bouché, F.; Tamseddak, K.; Ormenese, S.; Torti, S.; Coupland, G.; Périlleux, C. Cytokinin promotes flowering of Arabidopsis via transcriptional activation of the FT paralogue TSF. Plant J. 2011, 65, 972-979. [CrossRef]

120. Teper-Bamnolker, P.; Samach, A. The flowering integrator FT regulates SEPALLATA3 and FRUITFULL accumulation in Arabidopsis leaves. Plant Cell 2005, 17, 2661-2675. [CrossRef]

121. Lifschitz, E.; Eviatar, T.; Rozman, A.; Shalit, A.; Goldshmidt, A.; Amsellem, Z.; Alvarez, J.P.; Eshed, Y. The tomato FT ortholog triggers systemic signals that regulate growth and flowering and substitute for diverse environmental stimuli. Proc. Natl. Acad. Sci. USA 2006, 103, 6398-6403. [CrossRef] 
122. Giavalisco, P.; Kapitza, K.; Kolasa, A.; Buhtz, A.; Kehr, J. Towards the proteome of Brassica napus phloem sap. Proteomics 2006, 6, 896-909. [CrossRef] [PubMed]

123. Michaels, S.D.; Amasino, R.M. FLOWERING LOCUS C encodes a novel MADS domain protein that acts as a repressor of flowering Plant Cell 1999, 11, 949-956. [CrossRef]

124. Sheldon, C.C.; Burn, J.E.; Perez, P.P.; Metzger, J.; Edwards, J.A.; Peacock, W.J.; Dennis, E.S. The FLF MADS box gene: A repressor of flowering in Arabidopsis regulated by vernalization and methylation. Plant Cell 1999, 11, 445-458. [CrossRef] [PubMed]

125. Hartmann, U.; Höhmann, S.; Nettesheim, K.; Wisman, E.; Saedler, H.; Huijser, P. Molecular cloning of SVP: A negative regulator of the floral transition in Arabidopsis. Plant J. 2000, 21, 351-360. [CrossRef]

126. Fujiwara, S.; Oda, A.; Yoshida, R.; Niinuma, K.; Miyata, K.; Tomozoe, Y.; Tajima, T.; Nakagawa, M.; Hayashi, K.; Coupland, G. Circadian clock proteins LHY and CCA1 regulate SVP protein accumulation to control flowering in Arabidopsis. Plant Cell 2008, 20, 2960-2971. [CrossRef] [PubMed]

127. Li, D.; Liu, C.; Shen, L.; Wu, Y.; Chen, H.; Robertson, M.; Helliwell, C.A.; Ito, T.; Meyerowitz, E.; Yu, H. A repressor complex governs the integration of flowering signals in Arabidopsis. Dev. Cell 2008, 15, 110-120. [CrossRef]

128. Searle, I.; He, Y.; Turck, F.; Vincent, C.; Fornara, F.; Kröber, S.; Amasino, R.A.; Coupland, G. The transcription factor FLC confers a flowering response to vernalization by repressing meristem competence and systemic signaling in Arabidopsis. Genes Dev. 2006, 20, 898-912. [CrossRef]

129. Lee, J.H.; Yoo, S.J.; Park, S.H.; Hwang, I.; Lee, J.S.; Ahn, J.H. Role of SVP in the control of flowering time by ambient temperature in Arabidopsis. Genes Dev. 2007, 21, 397-402. [CrossRef]

130. Taoka, K.-i.; Ohki, I.; Tsuji, H.; Furuita, K.; Hayashi, K.; Yanase, T.; Yamaguchi, M.; Nakashima, C.; Purwestri, Y.A.; Tamaki, S 14-3-3 proteins act as intracellular receptors for rice Hd3a florigen. Nature 2011, 476, 332-335. [CrossRef]

131. Fornara, F.; Panigrahi, K.C.; Gissot, L.; Sauerbrunn, N.; Rühl, M.; Jarillo, J.A.; Coupland, G. Arabidopsis DOF transcription factors act redundantly to reduce CONSTANS expression and are essential for a photoperiodic flowering response. Dev. Cell 2009, 17, 75-86. [CrossRef]

132. Jaeger, K.E.; Pullen, N.; Lamzin, S.; Morris, R.J.; Wigge, P.A. Interlocking feedback loops govern the dynamic behavior of the floral transition in Arabidopsis. Plant Cell 2013, 25, 820-833. [CrossRef] [PubMed]

133. Pnueli, L.; Hareven, D.; Broday, L.; Hurwitz, C.; Lifschitz, E. The TM5 MADS box gene mediates organ differentiation in the three inner whorls of tomato flowers. Plant Cell 1994, 6, 175-186. [CrossRef]

134. Savidge, B.; Rounsley, S.D.; Yanofsky, M.F. Temporal relationship between the transcription of two Arabidopsis MADS box genes and the floral organ identity genes. Plant Cell 1995, 7, 721-733. [PubMed]

135. Yu, H.; Xu, Y.; Tan, E.L.; Kumar, P.P. AGAMOUS-LIKE 24, a dosage-dependent mediator of the flowering signals. Proc. Natl. Acad. Sci. USA 2002, 99, 16336-16341. [CrossRef] [PubMed]

136. Burgeff, C.; Liljegren, S.J.; Tapia-López, R.; Yanofsky, M.F.; Alvarez-Buylla, E.R. MADS-box gene expression in lateral primordia, meristems and differentiated tissues of Arabidopsis thaliana roots. Planta 2002, 214, 365-372. [CrossRef]

137. Adamczyk, B.J.; Fernandez, D.E. MIKC* MADS domain heterodimers are required for pollen maturation and tube growth in Arabidopsis. Plant Physiol. 2009, 149, 1713-1723. [CrossRef]

138. Portereiko, M.F.; Lloyd, A.; Steffen, J.G.; Punwani, J.A.; Otsuga, D.; Drews, G.N. AGL80 is required for central cell and endosperm development in Arabidopsis. Plant Cell 2006, 18, 1862-1872. [CrossRef]

139. Crane, P.R.; Friis, E.M.; Pedersen, K.R. The origin and early diversification of angiosperms. Nature 1995, 374, 27-33. [CrossRef]

140. Wu, F.; Shi, X.; Lin, X.; Liu, Y.; Chong, K.; Theißen, G.; Meng, Z. The ABC s of flower development: Mutational analysis of $A P$ 1/FUL-like genes in rice provides evidence for a homeotic (A)-function in grasses. Plant J. 2017, 89, 310-324. [CrossRef]

141. Xu, G.; Kong, H. Duplication and divergence of floral MADS-box genes in grasses: Evidence for the generation and modification of novel regulators. J. Integr. Plant Biol. 2007, 49, 927-939. [CrossRef]

142. Wang, K.; Tang, D.; Hong, L.; Xu, W.; Huang, J.; Li, M.; Gu, M.; Xue, Y.; Cheng, Z. DEP and AFO regulate reproductive habit in rice. PLoS Genet. 2010, 6, e1000818. [CrossRef] [PubMed]

143. Yadav, S.R.; Prasad, K.; Vijayraghavan, U. Divergent regulatory OsMADS2 functions control size, shape and differentiation of the highly derived rice floret second-whorl organ. Genetics 2007, 176, 283-294. [CrossRef] [PubMed]

144. Yoshida, H.; Itoh, J.I.; Ohmori, S.; Miyoshi, K.; Horigome, A.; Uchida, E.; Kimizu, M.; Matsumura, Y.; Kusaba, M.; Satoh, H. Superwoman1-cleistogamy, a hopeful allele for gene containment in GM rice. Plant Biotechnol. J. 2007, 5, 835-846. [CrossRef] [PubMed]

145. Yao, S.-G.; Ohmori, S.; Kimizu, M.; Yoshida, H. Unequal genetic redundancy of rice PISTILLATA orthologs, OsMADS2 and OsMADS4, in lodicule and stamen development. Plant Cell Physiol. 2008, 49, 853-857. [CrossRef]

146. Hama, E.; Takumi, S.; Ogihara, Y.; Murai, K. Pistillody is caused by alterations to the class-B MADS-box gene expression pattern in alloplasmic wheats. Planta 2004, 218, 712-720.

147. Yasui, Y.; Tanaka, W.; Sakamoto, T.; Kurata, T.; Hirano, H.-Y. Genetic enhancer analysis reveals that FLORAL ORGAN NUMBER2 and OsMADS3 co-operatively regulate maintenance and determinacy of the flower meristem in rice. Plant Cell Physiol. 2017, 58, 893-903. [CrossRef]

148. Dreni, L.; Jacchia, S.; Fornara, F.; Fornari, M.; Ouwerkerk, P.B.; An, G.; Colombo, L.; Kater, M.M. The D-lineage MADS-box gene OsMADS13 controls ovule identity in rice. Plant J. 2007, 52, 690-699. [CrossRef] 
149. Trevaskis, B.; Tadege, M.; Hemming, M.N.; Peacock, W.J.; Dennis, E.S.; Sheldon, C. Short vegetative phase-like MADS-box genes inhibit floral meristem identity in barley. Plant Physiol. 2007, 143, 225-235. [CrossRef]

150. Sentoku, N.; Kato, H.; Kitano, H.; Imai, R. OsMADS22, an STMADS11-like MADS-box gene of rice, is expressed in non-vegetative tissues and its ectopic expression induces spikelet meristem indeterminacy. Mol. Genet. Genom. 2005, 273, 1-9. [CrossRef]

151. Hu, Y.; Liang, W.; Yin, C.; Yang, X.; Ping, B.; Li, A.; Jia, R.; Chen, M.; Luo, Z.; Cai, Q. Interactions of OsMADS1 with floral homeotic genes in rice flower development. Mol. Plant 2015, 8, 1366-1384. [CrossRef]

152. Cui, R.; Han, J.; Zhao, S.; Su, K.; Wu, F.; Du, X.; Xu, Q.; Chong, K.; Theißen, G.; Meng, Z. Functional conservation and diversification of class $\mathrm{E}$ floral homeotic genes in rice (Oryza sativa). Plant J. 2010, 61, 767-781. [CrossRef]

153. Liu, Y.; Cui, S.; Wu, F.; Yan, S.; Lin, X.; Du, X.; Chong, K.; Schilling, S.; Theißen, G.; Meng, Z. Functional conservation of MIKC*-Type MADS box genes in Arabidopsis and rice pollen maturation. Plant Cell 2013, 25, 1288-1303. [CrossRef]

154. Zhang, D.; Wilson, Z.A. Stamen specification and anther development in rice. Chin. Sci. Bull. 2009, 54, 2342-2353. [CrossRef]

155. Kim, E.-J.; Hong, W.-J.; Kim, Y.-J.; Jung, K.-H. Transcriptome analysis of triple mutant for OsMADS62, OsMADS63, and OsMADS68 reveals the downstream regulatory mechanism for pollen germination in rice (Oryza sativa). Int. J. Mol. Sci. 2022, 23, 239. [CrossRef] [PubMed]

156. Han, M.-J.; Jung, K.-H.; Yi, G.; Lee, D.-Y.; An, G. Rice Immature Pollen 1 (RIP1) is a regulator of late pollen development. Plant Cell Physiol. 2006, 47, 1457-1472. [CrossRef]

157. Angenent, G.C.; Franken, J.; Busscher, M.; Weiss, D.; Van Tunen, A.J. Co-suppression of the petunia homeotic gene Fbp2 affects the identity of the generative meristem. Plant J. 1994, 5, 33-44. [CrossRef] [PubMed]

158. Pnueli, L.; Abu-Abeid, M.; Zamir, D.; Nacken, W.; Schwarz-Sommer, Z.; Lifschitz, E. The MADS box gene family in tomato: Temporal expression during floral development, conserved secondary structures and homology with homeotic genes from Antirrhinum and Arabidopsis. Plant J. 1991, 1, 255-266. [CrossRef] [PubMed]

159. Ma, H.; Yanofsky, M.F.; Meyerowitz, E.M. AGL1-AGL6, an Arabidopsis gene family with similarity to floral homeotic and transcription factor genes. Genes Dev. 1991, 5, 484-495. [CrossRef]

160. Liljegren, S.J.; Ditta, G.S.; Eshed, Y.; Savidge, B.; Bowman, J.L.; Yanofsky, M.F. SHATTERPROOF MADS-box genes control seed dispersal in Arabidopsis. Nature 2000, 404, 766-770. [CrossRef]

161. Jeon, J.-S.; Jang, S.; Lee, S.; Nam, J.; Kim, C.; Lee, S.-H.; Chung, Y.-Y.; Kim, S.-R.; Lee, Y.H.; Cho, Y.-G. Leafy hull sterile1 is a homeotic mutation in a rice MADS box gene affecting rice flower development. Plant Cell 2000, 12, 871-884. [CrossRef]

162. Wu, D.; Liang, W.; Zhu, W.; Chen, M.; Ferrándiz, C.; Burton, R.A.; Dreni, L.; Zhang, D. Loss of LOFSEP transcription factor function converts spikelet to leaf-like structures in rice. Plant Physiol. 2018, 176, 1646-1664. [CrossRef] [PubMed]

163. Zhang, H.; Xu, H.; Feng, M.; Zhu, Y. Suppression of OsMADS7 in rice endosperm stabilizes amylose content under high temperature stress. Plant Biotechnol. J. 2018, 16, 18-26. [CrossRef] [PubMed]

164. Kong, L.; Duan, Y.; Ye, Y.; Cai, Z.; Wang, F.; Qu, X.; Qiu, R.; Wu, C.; Wu, W. Screening and analysis of proteins interacting with OsMADS16 in rice (Oryza sativa L.). PLoS ONE 2019, 14, e0221473. [CrossRef] [PubMed]

165. Pelucchi, N.; Fornara, F.; Favalli, C.; Masiero, S.; Lago, C.; Pè, E.M.; Colombo, L.; Kater, M.M. Comparative analysis of rice MADS-box genes expressed during flower development. Sex. Plant Reprod. 2002, 15, 113-122. [CrossRef]

166. Yang, X.; Wu, F.; Lin, X.; Du, X.; Chong, K.; Gramzow, L.; Schilling, S.; Becker, A.; Theißen, G.; Meng, Z. Live and let die-the Bsister MADS-box gene OsMADS29 controls the degeneration of cells in maternal tissues during seed development of rice (Oryza sativa). PLoS ONE 2012, 7, e51435. [CrossRef] [PubMed]

167. Yin, L.-L.; Xue, H.-W. The MADS29 transcription factor regulates the degradation of the nucellus and the nucellar projection during rice seed development. Plant Cell 2012, 24, 1049-1065. [CrossRef]

168. Wen, K.; Chen, Y.; Zhou, X.; Chang, S.; Feng, H.; Zhang, J.; Chu, Z.; Han, X.; Li, J.; Liu, J. OsCPK21 is required for pollen late-stage development in rice. J. Plant Physiol. 2019, 240, 153000. [CrossRef]

169. Cheng, X.; Pan, M.; Zhiguo, E.; Zhou, Y.; Niu, B.; Chen, C. The maternally expressed polycomb group gene OsEMF2a is essential for endosperm cellularization and imprinting in rice. Plant Commun. 2021, 2, 100092. [CrossRef]

170. Ishikawa, R.; Ohnishi, T.; Kinoshita, Y.; Eiguchi, M.; Kurata, N.; Kinoshita, T. Rice interspecies hybrids show precocious or delayed developmental transitions in the endosperm without change to the rate of syncytial nuclear division. Plant J. 2011, 65, 798-806. [CrossRef]

171. Theissen, G.; Becker, A.; Di Rosa, A.; Kanno, A.; Kim, J.T.; Münster, T.; Winter, K.-U.; Saedler, H. A short history of MADS-box genes in plants. Plant Mol. Biol. 2000, 42, 115-149. [CrossRef]

172. Yu, L.-H.; Wu, J.; Zhang, Z.-S.; Miao, Z.-Q.; Zhao, P.-X.; Wang, Z.; Xiang, C.-B. Arabidopsis MADS-box transcription factor AGL21 acts as environmental surveillance of seed germination by regulating ABI5 expression. Mol. Plant 2017, 10, 834-845. [CrossRef]

173. Li, H.; Liang, W.; Hu, Y.; Zhu, L.; Yin, C.; Xu, J.; Dreni, L.; Kater, M.M.; Zhang, D. Rice MADS6 interacts with the floral homeotic genes SUPERWOMAN1, MADS3, MADS58, MADS13, and DROOPING LEAF in specifying floral organ identities and meristem fate. Plant Cell 2011, 23, 2536-2552. [CrossRef]

174. Nayar, S.; Kapoor, M.; Kapoor, S. Post-translational regulation of rice MADS29 function: Homodimerization or binary interactions with other seed-expressed MADS proteins modulate its translocation into the nucleus. J. Exp. Bot. 2014, 65, 5339-5350. [CrossRef] [PubMed]

175. Chen, C.; Begcy, K.; Liu, K.; Folsom, J.J.; Wang, Z.; Zhang, C.; Walia, H. Heat stress yields a unique MADS box transcription factor in determining seed size and thermal sensitivity. Plant Physiol. 2016, 171, 606-622. [CrossRef] [PubMed] 
176. Folsom, J.J.; Begcy, K.; Hao, X.; Wang, D.; Walia, H. Rice Fertilization-Independent Endosperm1 regulates seed size under heat stress by controlling early endosperm development. Plant Physiol. 2014, 165, 238-248. [CrossRef] [PubMed]

177. Bernardi, J.; Roig-Villanova, I.; Marocco, A.; Battaglia, R. Communicating across generations: The Bsister language. Plant Biosyst. Int. J. Deal. All Asp. Plant Biol. 2014, 148, 150-156.

178. Kofuji, R.; Sumikawa, N.; Yamasaki, M.; Kondo, K.; Ueda, K.; Ito, M.; Hasebe, M. Evolution and divergence of the MADS-box gene family based on genome-wide expression analyses. Mol. Biol. Evol. 2003, 20, 1963-1977. [CrossRef]

179. Yang, F.; Xu, F.; Wang, X.; Liao, Y.; Chen, Q.; Meng, X. Characterization and functional analysis of a MADS-box transcription factor gene (GbMADS9) from Ginkgo biloba. Sci. Hortic. 2016, 212, 104-114. [CrossRef]

180. Nesi, N.; Debeaujon, I.; Jond, C.; Stewart, A.J.; Jenkins, G.I.; Caboche, M.; Lepiniec, L. The TRANSPARENT TESTA16 locus encodes the ARABIDOPSIS BSISTER MADS domain protein and is required for proper development and pigmentation of the seed coat. Plant Cell 2002, 14, 2463-2479. [CrossRef]

181. De Folter, S.; Shchennikova, A.V.; Franken, J.; Busscher, M.; Baskar, R.; Grossniklaus, U.; Angenent, G.C.; Immink, R.G. A Bsister MADS-box gene involved in ovule and seed development in petunia and Arabidopsis. Plant J. 2006, 47, 934-946. [CrossRef]

182. Deng, W.; Chen, G.; Peng, F.; Truksa, M.; Snyder, C.L.; Weselake, R.J. Transparent testa16 plays multiple roles in plant development and is involved in lipid synthesis and embryo development in canola. Plant Physiol. 2012, 160, 978-989. [CrossRef] [PubMed]

183. Mizzotti, C.; Mendes, M.A.; Caporali, E.; Schnittger, A.; Kater, M.M.; Battaglia, R.; Colombo, L. The MADS box genes SEEDSTICK and ARABIDOPSIS Bsister play a maternal role in fertilization and seed development. Plant J. 2012, 70, 409-420. [CrossRef] [PubMed]

184. Erdmann, R.; Gramzow, L.; Melzer, R.; Theißen, G.; Becker, A. GORDITA (AGL63) is a young paralog of the Arabidopsis thaliana Bsister MADS box gene ABS (TT16) that has undergone neofunctionalization. Plant J. 2010, 63, 914-924. [CrossRef] [PubMed]

185. Herrera-Ubaldo, H.; Lozano-Sotomayor, P.; Ezquer, I.; Di Marzo, M.; Chávez Montes, R.A.; Gómez-Felipe, A.; Pablo-Villa, J.; Diaz-Ramirez, D.; Ballester, P.; Ferrándiz, C. New roles of NO TRANSMITTING TRACT and SEEDSTICK during medial domain development in Arabidopsis fruits. Development 2019, 146, dev172395. [CrossRef]

186. Di Marzo, M.; Roig-Villanova, I.; Zanchetti, E.; Caselli, F.; Gregis, V.; Bardetti, P.; Chiara, M.; Guazzotti, A.; Caporali, E.; Mendes, M.A. MADS-box and bHLH transcription factors coordinate transmitting tract development in Arabidopsis thaliana. Front. Plant Sci. 2020, 11, 526. [CrossRef]

187. Balanzà, V.; Roig-Villanova, I.; Di Marzo, M.; Masiero, S.; Colombo, L. Seed abscission and fruit dehiscence required for seed dispersal rely on similar genetic networks. Development 2016, 143, 3372-3381. [CrossRef]

188. Ezquer, I.; Mizzotti, C.; Nguema-Ona, E.; Gotté, M.; Beauzamy, L.; Viana, V.E.; Dubrulle, N.; Costa de Oliveira, A.; Caporali, E.; Koroney, A.-S. The developmental regulator SEEDSTICK controls structural and mechanical properties of the Arabidopsis seed coat. Plant Cell 2016, 28, 2478-2492. [CrossRef]

189. Paolo, D.; Rotasperti, L.; Schnittger, A.; Masiero, S.; Colombo, L.; Mizzotti, C. The Arabidopsis MADS-domain transcription factor SEEDSTICK controls seed size via direct activation of E2Fa. Plants 2021, 10, 192. [CrossRef]

190. Di Marzo, M.; Viana, V.E.; Banfi, C.; Cassina, V.; Corti, R.; Herrera-Ubaldo, H.; Babolin, N.; Guazzotti, A.; Kiegle, E.; Gregis, V. Cell wall modifications by $\alpha$-XYLOSIDASE1 are required for the control of seed and fruit size. J. Exp. Bot. 2021. [CrossRef]

191. Khong, G.N.; Pati, P.K.; Richaud, F.; Parizot, B.; Bidzinski, P.; Mai, C.D.; Bès, M.; Bourrié, I.; Meynard, D.; Beeckman, T. OsMADS26 negatively regulates resistance to pathogens and drought tolerance in rice. Plant Physiol. 2015, 169, 2935-2949. [CrossRef]

192. Rensink, W.A.; Buell, C.R. Arabidopsis to rice. Applying knowledge from a weed to enhance our understanding of a crop species. Plant Physiol. 2004, 135, 622-629. [CrossRef] [PubMed]

193. Ram, H.; Soni, P.; Salvi, P.; Gandass, N.; Sharma, A.; Kaur, A.; Sharma, T.R. Insertional mutagenesis approaches and their use in rice for functional genomics. Plants 2019, 8, 310. [CrossRef] [PubMed]

194. Hong, W.-J.; Jung, K.-H. Comparative analysis of flanking sequence tags of T-DNA/transposon insertional mutants and genetic variations of fast-neutron treated mutants in rice. J. Plant Biol. 2018, 61, 80-84. [CrossRef]

195. Bortesi, L.; Fischer, R. The CRISPR/Cas9 system for plant genome editing and beyond. Biotechnol. Adv. 2015, 33, 41-52. [CrossRef]

196. Montecillo, J.A.V.; Chu, L.L.; Bae, H. CRISPR-Cas9 system for plant genome editing: Current approaches and emerging developments. Agronomy 2020, 10, 1033. [CrossRef]

197. Wu, J.-L.; Wu, C.; Lei, C.; Baraoidan, M.; Bordeos, A.; Madamba, M.R.S.; Ramos-Pamplona, M.; Mauleon, R.; Portugal, A.; Ulat, V.J. Chemical-and irradiation-induced mutants of indica rice IR64 for forward and reverse genetics. Plant Mol. Biol. 2005, 59, 85-97. [CrossRef] [PubMed]

198. Jankowicz-Cieslak, J.; Till, B.J. Chemical mutagenesis of seed and vegetatively propagated plants using EMS. Curr. Protoc. Plant Biol. 2016, 1, 617-635. [CrossRef]

199. Aklilu, E. Review on forward and reverse genetics in plant breeding. All Life 2021, 14, 127-135. [CrossRef] 